\title{
Ecto-Nucleotidases and Nucleoside Transporters Mediate Activation of Adenosine Receptors on Hippocampal Mossy Fibers by $\mathrm{P} 2 \mathrm{X}_{7}$ Receptor Agonist $2^{\prime}$-3'-O-(4-Benzoylbenzoyl)-ATP
}

\author{
Maria Kukley, ${ }^{1}$ Pia Stausberg, ${ }^{1}$ Giselind Adelmann, ${ }^{2}$ Iain P. Chessell, ${ }^{3}$ and Dirk Dietrich ${ }^{1}$ \\ ${ }^{1}$ Department of Neurosurgery, University Clinic Bonn, D-53105 Bonn, Germany, ${ }^{2}$ Department of Anatomy and Cell Biology, University Freiburg, D-79104 \\ Freiburg, Germany, and ${ }^{3}$ Pain Research, GlaxoSmithKline, Harlow CM19 5AD, United Kingdom
}

\begin{abstract}
The ionotropic and cytolytic $\mathrm{P} 2 \mathrm{X}_{7}$ receptor is typically found on immune cells, where it is involved in the release of cytokines. Recently, $\mathrm{P} 2 \mathrm{X}_{7}$ receptors were reported to be localized to presynaptic nerve terminals and to modulate transmitter release. In the present study, we reassessed this unexpected role of $\mathrm{P} 2 \mathrm{X}_{7}$ receptors at hippocampal mossy fiber-CA3 synapses. In agreement with previous findings, the widely used P2X 7 agonist 2'-3'-O-(4-benzoylbenzoyl)-adenosine-5' -triphosphate (BzATP) clearly depressed field potentials (fEPSPs); however, no evidence for an involvement of $\mathrm{P}_{2} \mathrm{X}_{7}$ receptors could be obtained. First, depression of fEPSPs by BzATP was unchanged in $\mathrm{P}_{2} \mathrm{X}_{7}{ }^{-l-}$ mice. Second, experiments using $\mathrm{P} 2 \mathrm{X}_{7}{ }^{-l-}$ mice, immunohistochemistry, and electron microscopy showed that the antigen detected by frequently used $\mathrm{P} 2 \mathrm{X}_{7}$ antibodies is not compatible with a plasmalemmal P2X $\mathrm{X}_{7}$ receptor. Third, BzATP did not alter Ca ${ }^{2+}$ levels in synaptic terminals. In contrast, the depression of fEPSPs by BzATP was fully blocked by adenosine $\left(A_{1}\right)$ receptor antagonists. Furthermore, the application of BzATP also activated postsynaptic $\mathrm{A}_{1}$ receptor-coupled $\mathrm{K}^{+}$channels. This effect of BzATP was mimicked by ATP and adenosine and was completely prevented by enzymes specifically degrading adenosine. Activation of $\mathrm{A}_{1}$-coupled $\mathrm{K}^{+}$channels by BzATP was dependent on ecto-nucleotidases, extracellular enzymes that convert ATP to adenosine. Moreover, the opening of $\mathrm{A}_{1}$-coupled $\mathrm{K}^{+}$channels by BzATP was dependent on nucleoside transporters. Taken together, our results indicate that BzATP is extracellularly catabolized to Bz-adenosine and subsequently hetero-exchanged for intracellular adenosine and then depresses mossy fiber fEPSPs through presynaptic $\mathrm{A}_{1}$ receptors rather than through $\mathrm{P} 2 \mathrm{X}_{7}$ receptors. Thus, the present study casts doubts on the neuronal localization of $\mathrm{P} 2 \mathrm{X}_{7}$ receptors in rodent hippocampus.
\end{abstract}

Key words: SB 203580; presynaptic; $\mathrm{Ca}^{2+}$ imaging; ecto-nucleotidases; nucleoside transporter; transmitter release

\section{Introduction}

In addition to its classic role as an intracellular energy source, ATP is now recognized as an extracellular signaling molecule that acts at two distinct classes of receptors: metabotropic P2Y and ionotropic P2X receptors (Ralevic and Burnstock, 1998). P2X receptors are nonselective cation channels, form a family of at least seven subunits $\left(\mathrm{P}_{2} \mathrm{X}_{1}-\mathrm{P} 2 \mathrm{X}_{7}\right)$, and are expressed in various neuronal and non-neuronal tissues (for review, see North, 2002). The most unequivocal functional role of neuronal $\mathrm{P} 2 \mathrm{X}$ receptors $\left(\mathrm{P} 2 \mathrm{X}_{1}-\mathrm{P} 2 \mathrm{X}_{6}\right)$ is the processing of pain as presynaptic and postsynaptic receptors in spinal cord and dorsal root ganglion

\footnotetext{
Received May 30, 2004; revised July 1, 2004; accepted July 4, 2004.

This study was supported by the Deutsche Forschungsgemeinschaft (SFB TR3 and GK 246), University Clinic Bonn grants (BONFOR), and the Gertrud-Reemtsma-Stiftung of the Max-Planck-Gesellschaft. We are grateful to H. Zimmermann, K.-N. Klotz, and H. Beck for helpful comments on a previous version of this manuscript. We thank G. Seifert for assistance in establishing PCR protocols.

Correspondence should be addressed to Dr. Dirk Dietrich, Department of Neurosurgery, NCH U1 R035, Experimental Neurophysiology, University Clinic Bonn, Sigmund-Freud Strasse 25, D-53105 Bonn, Germany. E-mail: dirk.dietrich@ukb.uni-bonn.de.

DOl:10.1523/JNEUROSCI.2093-04.2004

Copyright $\odot 2004$ Society for Neuroscience $\quad 0270-6474 / 04 / 247128-12 \$ 15.00 / 0$
}

cells (Chizh and Illes, 2001; Khakh, 2001). In addition, a role for $\mathrm{P} 2 \mathrm{X}$ receptors in neurotransmission and modulation of transmitter release has been described at certain central synapses (Edwards et al., 1992; Nieber et al., 1997; Khakh and Henderson, 1998; Pankratov et al., 1998; Khakh et al., 1999, 2003; Norenberg and Illes, 2000; Kato and Shigetomi, 2001; North, 2002). In contrast to $\mathrm{P} 2 \mathrm{X}_{1}-\mathrm{P} 2 \mathrm{X}_{6}$, the expression and function of $\mathrm{P} 2 \mathrm{X}_{7}$ in nervous tissue are still unclear (Norenberg and Illes, 2000; Chizh and Illes, 2001). P2X $\mathrm{X}_{7}$ receptors are cationic channels as well, but they display several differences from the other subtypes. $\mathrm{P}_{2} \mathrm{X}_{7}$ receptors form large diameter cytolytic pores in the continuous presence of an agonist (Surprenant, 1996), and their specialized C-terminal domain enables them to couple to various intracellular signaling cascades (Denlinger et al., 2001). Typically, $\mathrm{P}_{2} \mathrm{X}_{7}$ receptors are located on immune cells, mediate the release of cytokines (Le Feuvre et al., 2002), and are involved in the induction of cell death (Brough et al., 2002). With the exception of retina and auditory spiral ganglion (Brandle et al., 1998, 1999), $\mathrm{P}_{2} \mathrm{X}_{7} \mathrm{mRNA}$ and protein have not been found in adult rat brain parenchyma (Collo et al., 1997).

It was reported recently, however, that $\mathrm{P} 2 \mathrm{X}_{7}$ subunits are 
localized on presynaptic terminals and modulate transmitter release onto hippocampal and spinal cord neurons (Deuchars et al., 2001; Armstrong et al., 2002; Sperlagh et al., 2002). The presence of $\mathrm{Ca}^{2+}$-permeable $\mathrm{P} 2 \mathrm{X}_{7}$ receptors on hippocampal mossy fiber terminals (Armstrong et al., 2002; Sperlagh et al., 2002) would be particularly intriguing, because mossy fiber synapses display several forms of short and long-term synaptic plasticity that depend on the accumulation of presynaptic $\mathrm{Ca}^{2+}$ (Castillo et al., 1994; Regehr et al., 1994; Salin et al., 1996; Dietrich et al., 2003). Because the endogenous ligand ATP is released by hippocampal slices (Wieraszko et al., 1989; Cunha et al., 1996; Inoue, 1998), presynaptic $\mathrm{P}_{2} \mathrm{X}_{7}$ receptors could exert an activity-dependent modulation of mossy fiber synaptic transmission. So far, however, results are conflicting, because on application of the (nonselective) $\mathrm{P}_{2} \mathrm{X}_{7}$ agonist $2^{\prime}-3^{\prime}-\mathrm{O}$-(4-benzoylbenzoyl)-adenosine$5^{\prime}$-triphosphate (BzATP) (North, 2002), one group reported an increase (Sperlagh et al., 2002) and another group reported an inhibition (Armstrong et al., 2002) of transmitter release.

A potential problem when studying the functional role of $\mathrm{P} 2 \mathrm{X}$ receptors in native tissue such as brain slices is that many of the commonly used agonists, ATP and analogs, are subject to rapid breakdown to adenosine by extracellular enzymes called "ectonucleotidases” (Dunwiddie et al., 1997; Cunha et al., 1998; Zimmermann and Braun, 1999; Zimmermann, 2000). These nucleotidases lead to formation of sufficient levels of adenosine to activate presynaptic and postsynaptic adenosine $A_{1}$ receptors after application of even micromolar concentrations of ATP onto hippocampal slices (Dunwiddie et al., 1997; Cunha et al., 1998). It has not been determined whether the commonly used P2X agonist, BzATP, is catabolized by ecto-nucleotidases as well. Therefore, in the present study we reassessed the suggested role of $\mathrm{P} 2 \mathrm{X}_{7}$ receptors in the modulation of transmitter release at the mossy fiber-CA3 synapse. Although we confirm that application of BzATP produces a pronounced inhibition of mossy fiber synaptic transmission, our conclusions regarding the involved mechanism are completely different from those published previously (Armstrong et al., 2002). Our results suggest that BzATP is catabolized by hippocampal slices and that the observed effects of BzATP are caused by activation of adenosine receptors and require enzymatic conversion by ecto-nucleotidases to $\mathrm{Bz}$ adenosine and a heteroexchange with cellular adenosine via nucleoside transporters.

\section{Materials and Methods}

Slice preparation. Hippocampal slices (400 $\mu \mathrm{m}$ thick) were prepared from 20- to 40-d-old Wistar rats (Charles River, Munich, Germany) or adult mice (see below). Animals were anesthetized with chloroform and decapitated, and the brain was cooled and blocked in a solution of the following composition (in $\mathrm{mm}$ ): $87 \mathrm{NaCl}, 2.5 \mathrm{KCl}, 1.25 \mathrm{NaH}_{2} \mathrm{PO}_{4}, 7$ $\mathrm{MgSO}_{4}, 0.5 \mathrm{CaCl}_{2}, 25 \mathrm{NaHCO}_{3}, 25$ glucose, 75 sucrose, gassed with a $95 \% \mathrm{O}_{2}$ and $5 \% \mathrm{CO}_{2}$ mixture. Horizontal hippocampal slices were cut with a vibrating blade microtome (Leica Microsystems, Nussloch, Germany). Slices were quickly transferred to an interface incubation chamber and allowed to recover at $34^{\circ} \mathrm{C}$ for $30 \mathrm{~min}$ in solution of a composition similar to that used for the preparation. Slices were then stored at room temperature in artificial CSF (ACSF) containing (in mM): 124 $\mathrm{NaCl}, 3 \mathrm{KCl}, 1.25 \mathrm{NaH}_{2} \mathrm{PO}_{4}, 2 \mathrm{MgSO}_{4}, 2 \mathrm{CaCl}_{2}, 26 \mathrm{NaHCO}_{3}, 10$ glucose, $\mathrm{pH} 7.4$, osmolarity $300 \mathrm{mOsm}, \mathrm{pH} 7.4$, gassed with a $95 \% \mathrm{O}_{2}$ and $5 \% \mathrm{CO}_{2}$ mixture. At least $1 \mathrm{hr}$ after preparation, individual slices were transferred to a submerged recording chamber mounted on the stage of an upright Nikon microscope (Nikon E600FN) and superfused continuously $(2 \mathrm{ml} / \mathrm{min})$ with gassed ACSF. Drugs were added to this superfusion solution. In some cases (see Results), slices were preincubated for 45-60 min with drugs [inosine $5^{\prime}$-triphosphate trisodium salt (ITP), 4-[5-(4-fluorophenyl)-2-[4-(methylsulfonyl)phenyl]-1 $\mathrm{H}$-imidazol-4- yl]pyridine (SB 203580), 6- $N, N$-diethyl- $\beta$ - $\gamma$-dibromomethylene-Dadenosine- $5^{\prime}$-triphosphate trisodium salt (ARL 67156), concanavalin A]. During that time, slices were kept in a small volume gassed interfacelike chamber in the presence of the drug. For control purposes, slices were kept under the same conditions but without the drug addition. Because the responses obtained from slices without preincubation and from slices preincubated without drug were not different, data were pooled and taken as a common control group.

Electrophysiological voltage-clamp recordings. Whole-cell voltageclamp experiments were performed using patch pipettes pulled from borosilicate glass on a vertical puller (model PP-830, Narishige, Tokyo, Japan). Electrodes had a resistance of 4-5 $\mathrm{M} \Omega$ when filled with our internal solution containing (in $\mathrm{mm}$ ): 125 potassium gluconate, 10 HEPES, 0.5 EGTA, $2 \mathrm{MgCl}_{2}$ 2, $23 \mathrm{KCl}, 3 \mathrm{NaCl}$, pH adjusted to 7.3 with $\mathrm{KOH}$, osmolarity $280-290 \mathrm{mOsm} / \mathrm{kg}$. Voltages were corrected for the liquid junction potential by offsetting the amplifier to $-6 \mathrm{mV}$ before seal formation. Tetrodotoxin (TTX) (500 nM) and kynurenic acid (2 mM) were included in the standard external solution (above-mentioned ACSF). Pyramidal cells were located visually in the CA1 or CA3 somal layer using infrared differential interference contrast videomicroscopy. Cells were voltage clamped at $-65 \mathrm{mV}$ with a patch clamp L/M-EPC 7 amplifier (HEKA, Lambrecht-Pfalz, Germany). Holding current was averaged over several hundred milliseconds every $2 \mathrm{sec}$. The access resistance was determined from the current response to a $-5 \mathrm{mV}$ hyperpolarizing voltage command step every $2 \mathrm{sec}$ and was typically $10-25 \mathrm{M} \Omega$. The responses were low-pass filtered at $1-2 \mathrm{kHz}$, digitized with a sampling frequency of $20 \mathrm{kHz}$ (ITC-16, HEKA), and analyzed using Igor Pro software (WaveMetrics, Lake Oswego, OR).

Extracellular electrophysiological recordings. Extracellular recordings of the field EPSPs (fEPSPs) were made using glass microelectrodes (2-4 $\mathrm{M} \Omega$ ) filled with ACSF and placed under visual guidance in stratum lucidum of the CA3 region. Monopolar stimulation (rectangular pulses of $0.1 \mathrm{msec}$ applied once every $30 \mathrm{sec}$ ) of mossy fibers was delivered through a glass electrode (resistance $1 \mathrm{M} \Omega$ ) placed in stratum lucidum. The mossy fiber origin of fEPSPs was verified at the end of each experiment by application of $2 S, 2^{\prime} R, 3^{\prime} R-2-\left(2^{\prime}, 3^{\prime}\right.$-dicarboxycyclopropyl)glycine (DCG-IV) $(1 \mu \mathrm{M})$. The experiments were included only if the inhibition produced by DCG-IV was $>75 \%$. fEPSPs were recorded with a SEC-05L amplifier (npi Electronics, Tamm, Germany), filtered at $3 \mathrm{kHz}$, and digitized at 20 $\mathrm{kHz}$. The peak amplitudes of the fEPSPs were analyzed using Igor Pro software, and the responses were normalized to average value calculated 10-20 min before BzATP application and expressed in percentage.

In vitro analysis of hydrolysis of ATP analogs. Catabolism of ATP, BzATP, $\alpha \beta$-methylene-ATP ( $\alpha \beta$-MeATP), and $\alpha \beta$-MeADP was analyzed by incubating these substrates with enzymes and measuring the amount of inorganic phosphate $\left(\mathrm{P}_{\mathrm{i}}\right)$ released. The phosphate concentration was determined spectrophotometrically using the $P_{i}$ Per Phosphate Assay kit (P-22061, Molecular Probes, Leiden, The Netherlands) according to the protocol provided by the manufacturer. We used commercially available purified members of the nucleoside triphosphate diphosphohydrolases (NTPDase) family and ecto-5'-nucleotidase (5NTase) (apyrase, E.C. 3.6.1.5 and 5' -nucleotidase, E.C. 3.1.3.5; Sigma, Deisenhofen, Germany) because it is known that those enzymatic activities are present in hippocampal slices (Cunha et al., 1992, 1998, 2000; Braun et al., 2000; Boeck et al., 2002; Bruno et al., 2002). To compare the amount of $\mathrm{P}_{\mathrm{i}}$ released from the various substrates (see Fig. 5A), we proceeded as follows: $250 \mu \mathrm{l}$ of reaction solution containing $100 \mathrm{~mm}$ Tris- $\mathrm{HCl}, \mathrm{pH} 7.5$, $60 \mu \mathrm{M}$ substrate, $2 \mathrm{mM} \mathrm{CaCl}_{2}$, and $0.5 \mathrm{U}$ of each enzyme was incubated for $10 \mathrm{~min}$ at $35^{\circ} \mathrm{C}$. After that time, $250 \mu \mathrm{l}$ of the detector kit reagents was added. Over the next $45 \mathrm{~min}$, the free phosphates initiated a chain of enzymatic reactions (provided by the kit) that finally converts Amplex Red to the fluorescent resorufin. Resorufin absorption was measured at $560 \mathrm{~nm}$. In each run we included two to five vials containing standard $\mathrm{P}_{\mathrm{i}}$ concentrations of $20-100 \mu \mathrm{M}$ and an "empty" vial containing only Tris and $\mathrm{CaCl}_{2}$. In a subset of experiments, we also included "no-substrate" and "no-enzyme" controls that produced essentially the same absorption as the empty vials (some no-enzyme controls are shown in Fig. $5 A$ ). Values of $\Delta$ absorption ( $\Delta$ abs) were measured as the difference between the absorption of the empty and the test vial. In the $\mathrm{P}_{\mathrm{i}}$ concentration 
range of interest, $\Delta$ abs was linearly related to $P_{i}$ concentration, and the amount of $P_{i}$ released from the substrates was determined by interpolation of $\Delta$ abs values of the $\mathrm{P}_{\mathrm{i}}$ standards. To compare the apparent affinity of enzymes for ATP and BzATP (see Fig. 5B), we decreased the enzyme activity 10 -fold and $\mathrm{CaCl}_{2}$ concentration 100 -fold. This slowed the reaction and made it possible to compare the initial accumulation of phosphate $(1 \mathrm{~min})$ during nearly constant substrate concentration. Three vials with BzATP and three vials with ATP were started together with a control vial by adding the substrates. The reaction in the different vials was stopped after 1,3 , and $6 \mathrm{~min}$ at $35^{\circ} \mathrm{C}$ by cooling down and adding the reagents of the detector kit that were supplemented for this experiment by $10 \mathrm{~mm}$ EDTA. The control vial was identical to the others (either ATP or BzATP) but the EDTA-kit reagent mixture was added at time $0 . \Delta \mathrm{abs}$ was calculated as the difference between the test and the control vial and normalized for each run on the 6 min value of ATP.

Confocal calcium imaging. For imaging of intraterminal $\mathrm{Ca}^{2+}$ transients, mossy fibers were loaded with the high-affinity $\mathrm{Ca}^{2+}$ indicator Oregon Green acetoxymethyl ester (Molecular Probes) as described previously for other indicators (Dietrich et al., 2003). Briefly, a small amount of Oregon Green acetoxymethyl ester was dissolved in DMSO containing $20 \%$ pluronic acid and pressure injected in the stratum lucidum of hippocampal slices maintained in an interface chamber. After a period of at least $60 \mathrm{~min}$ to allow the indicator to diffuse along the presynaptic fibers, individual slices were placed in a submerged chamber in which ITP (2 $\mathrm{mm}$ ) was added to ACSF gassed with a $95 \% \mathrm{O}_{2}$ and $5 \% \mathrm{CO}_{2}$ mixture. Slices were transferred to the stage of a confocal microscope (Zeiss LSM5 Pascal, Axioskop FS 2) 45-60 min later and superfused with ACSF containing $2 \mathrm{~mm}$ ITP and Trolox $(15 \mathrm{mg} / \mathrm{ml})$ at room temperature. To ensure that mossy fibers were viable, a stimulating electrode filled with ACSF was placed distal to the indicator injection site, and the fibers were stimulated to record action potential-induced $\mathrm{Ca}^{2+}$ entry. Line scans were obtained perpendicular to the orientation of the mossy fiber bundle (see Fig. $6 A$, left). After that, TTX $(0.5 \mu \mathrm{M})$ was added to the bath solution. Scanning mode was changed to the frame scan mode, and fluorescence in the region of interest (ROI) (see Fig. $6 \mathrm{~A}$, left) was acquired each $10 \mathrm{sec}$. Excitation wavelength was $488 \mathrm{~nm}$, and the emitted fluorescence (long-pass filtered at $505 \mathrm{~nm}$ ) was collected by a $40 \times$ objective lens. The pinhole was set to maximal size. Relative changes in the intraterminal $\mathrm{Ca}^{2+}$ concentration were quantified as changes in mean fluorescence intensity in the ROI, normalized to average value $5 \mathrm{~min}$ before drug application, and expressed in percentage.

Immunohistochemistry. The animals were anesthetized with ethyl ether and decapitated. The brains were removed, and $4-5 \mathrm{~mm}$ blocks of hippocampal tissue were dissected out and placed in $8 \%$ paraformaldehyde (overnight); $40-\mu \mathrm{m}$-thick sections of the hippocampus were cut with a vibratome. The sections were then incubated with rabbit anti-P2X $\mathrm{X}_{7}$ antibodies (dilutions 1:50, 1:500, 1:1000; catalog \#APR-004; Alomone Labs, Jerusalem, Israel) in TBS containing $0.3 \%$ Triton X-100 for $24 \mathrm{hr}$ at $4^{\circ} \mathrm{C}$. Secondary biotinylated goat anti-rabbit IgGs (1:200; Vector Labs, Burlingame, CA) were applied overnight, followed by overnight application of streptavidin-conjugated Cy3 (1:250; Jackson ImmunoResearch, West Grove, PA). Green fluorescent Nissl stain ("Neurotrace"; Molecular Probes) was used in some cases for counterstaining. Sections were analyzed with a confocal laser scanning microscope (Leica TCS NT), and images with different dyes were scanned sequentially.

EM immunocytochemistry. Two Wistar rats were deeply anesthetized with an overdose of Narkodorm-n ( $250 \mathrm{mg} / \mathrm{kg}$ body weight) and perfused transcardially with $0.9 \%$ saline followed by a fixative containing $4 \%$ paraformaldehyde, $0.1 \%$ glutaraldehyde, and $0.2 \%$ picric acid in $0.1 \mathrm{M}$ phosphate buffer, $\mathrm{pH}$ 7.4. Brains were removed and postfixed in the same fixative overnight, cut on a vibratome into $300 \mu \mathrm{m}$ sections, and the CA3 area of the hippocampus was excised. The tissue blocks were cryoprotected in glycerol, cryofixed in nitrogen-cooled propane, substituted in methanol containing 1.5\% uranylacetate, and embedded in Lowicryl HM20 (Chemische Werke Lowi, Waldkraiburg, Germany). Ultrathin sections were processed for postembedding immunocytochemistry, using an anti-P2X $\mathrm{X}_{7}$ antibody (dilution 1:40; Alomone Labs) in TBS containing $0.9 \% \mathrm{NaCl}$. Immunolabeling was visualized by a $10 \mathrm{~nm}$ goldcoupled secondary antibody (1:20; British BioCell International, Cardiff,
Wales, UK). Control sections (stained with all but the primary antibody) were included in the same incubation procedure.

P2 $X_{7}$ knock-out mice. We used two different strains of $\mathrm{P} 2 \mathrm{X}_{7}$ knock-out mice that have been described previously (Sikora et al., 1999; Solle et al., 2001). In one of these strains (Solle et al., 2001) (generously supplied by Pfizer, Ann Arbor, MI), the region of P2X7 gene encoding Cys ${ }^{506}$ to $\mathrm{Pro}^{532}$ is replaced with the neomycin resistance gene, resulting in the disruption of the $\mathrm{C}$ terminus of the receptor to which the anti-P2 $\mathrm{X}_{7}$ antibody (Alomone Labs) binds. We confirmed the absence of this sequence in DNA preparations obtained from the tail and from hippocampal tissue (whole-mount preparation) using PCR analysis. The following primers were used: for WT: 5'-GCA GCC CAG CCC TGA TAC AGA CAT T- ${ }^{\prime}$ and $5^{\prime}$-TCG GGA CAG CAC GAG CTT ATG GA-3'; for KO: 5'-ACA TCG CAT CGA GCG AGC AC-3' and 5'-AAG GCG ATG CGC TGC GAA TC-3'. The other strain of mice carried a targeted null mutation of the $\mathrm{P}_{2} \mathrm{X}_{7}$ gene and were generated according to published protocols (Conquet, 1995). The $\mathrm{P} 2 \mathrm{X}_{7}$ gene was isolated from a genomic library obtained from $129 / \mathrm{Sv}$ mice. Partial sequencing of the $5^{\prime}$ exons permitted ligation of two fragments into the neomycin-resistant "knock-out vector" pGN, a plasmid described previously (Le Mouellic et al., 1990). Homologous recombination of the resulting plasmid DNA into embryonic stem cells resulted in a disrupted $\mathrm{P} 2 \mathrm{X}_{7}$ gene. Germline chimeras were crossed with $\mathrm{C} 57 \mathrm{BL} / 6 \mathrm{~J}$ females to generate heterozygotes and then intercrossed, giving rise to overtly healthy mutant offspring in the expected Mendelian ratio. Successful targeting and transmission were confirmed by Southern and Western analysis (Collo et al., 1997), by PCR, and by monitoring loss of channel function, using ATP-activated YOPRO-1 permeation of peritoneal macrophages. An additional six backcrosses onto the C57BL/6J strain were performed before homozygotes were produced for study.

Statistical analysis. Data are given as mean \pm SEM. Level of statistical significance was set to $\alpha=0.05$.

Drugs and reagents. ATP, BzATP, $\alpha, \beta$-MeATP, $\alpha, \beta$-MeADP, ITP, concanavalin A, adenosine deaminase (type VI, $183 \mathrm{U} / \mathrm{mg}$ protein, EC 3.5.4.4), and ionomycin were from Sigma (Taufkirchen, Germany). ARL 67156, SB 203580, and adenosine were from Tocris (Bristol, UK).

\section{Results}

BzATP-induced depression of mossy fiber synaptic transmission is reversed by an adenosine $A_{1}$ receptor antagonist

In the first series of experiments, we investigated the sensitivity of mossy fiber synaptic transmission to application of the $\mathrm{P} 2 \mathrm{X}_{7}$ agonist BzATP (Ralevic and Burnstock, 1998; Khakh et al., 2001). $\operatorname{BzATP}(65 \mu \mathrm{M})$ inhibited mossy fiber fEPSPs by $41 \pm 4 \%(n=4)$ (Fig. 1 A,C), similar to a previous report (Armstrong et al., 2002). Armstrong et al. (2002) assumed that this effect was caused by the activation of $\mathrm{P} 2 \mathrm{X}_{7}$ receptors on mossy fiber terminals by BzATP; however, because mossy fiber transmission is also sensitive to the action of adenosine via presynaptic inhibitory $A_{1}$ receptors (Okada and Ozawa, 1980; Scanziani et al., 1992) and hippocampal slices can potently convert ATP and various analogs to adenosine within several hundred milliseconds (Dunwiddie et al., 1997; Cunha et al., 1998), we asked whether the depression induced by BzATP could be reversed by $A_{1}$ antagonists. Indeed, the specific $A_{1}$ receptor antagonist 8-cyclopentyl-1,3-dipropylxanthine (DPCPX) (Lohse et al. (1987), reversed the effect of BzATP (Fig. 1A). Similarly, the BzATP-induced depression was completely abolished if DPCPX (1 $\mu \mathrm{M})$ was preapplied (Fig. $1 B, C)(n=3 ; p<0.001)$. It should be noted, however, that $1 \mu \mathrm{M}$ DPCPX possibly blocks $\mathrm{A}_{2 \mathrm{~B}}$ receptors as well (see Discussion).

\section{BzATP leads to activation of an $A_{1}$ receptor-coupled potassium conductance}

If application of BzATP leads to the activation of presynaptic $A_{1}$ receptors on mossy fiber terminals, e.g., after enzymatic conver- 

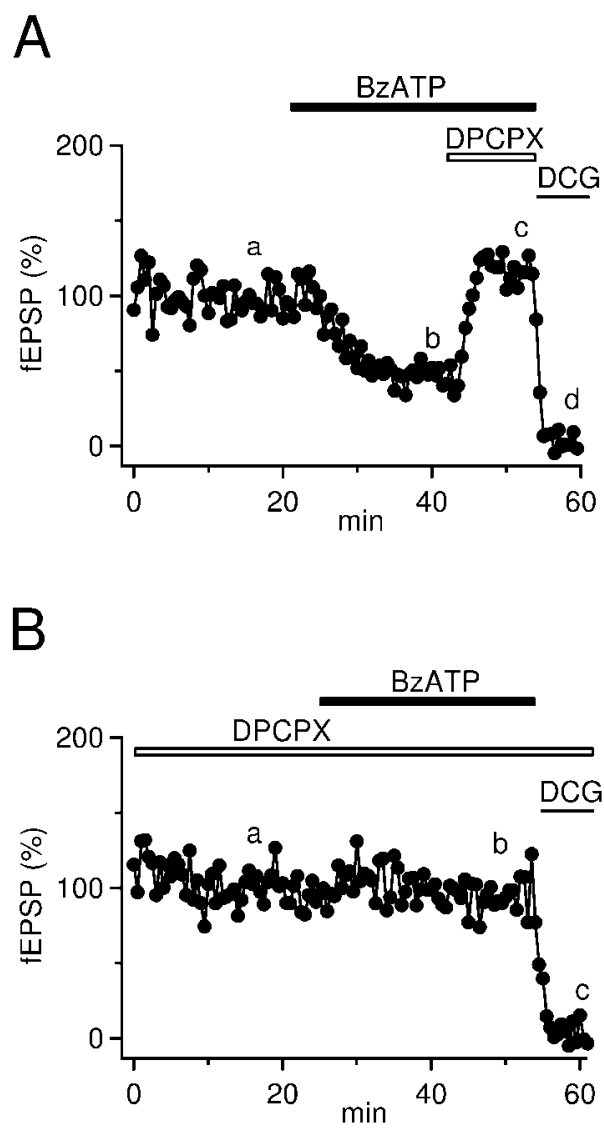

C

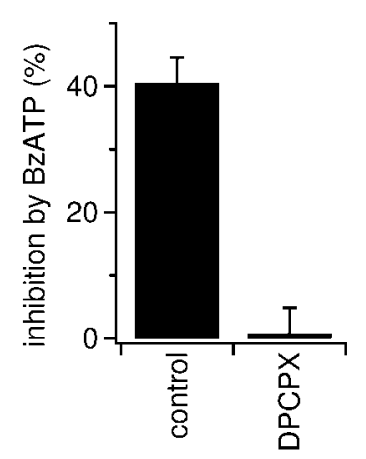

Figure 1. Inhibition of mossy fiber fEPSPs by BzATP is reversed by $\mathrm{A}_{1}$ antagonists. $A$, Time course of fEPSP amplitudes and example traces (average of 5-8 sweeps) from time points indicated by lowercase letters. DPCPX (1 $\mu \mathrm{M})$ reverses the depression of fEPSPs by BZATP $(65 \mu \mathrm{M})$; $1 \mu \mathrm{M} D C G-I V$ was used to confirm the mossy fiber origin of fEPSPs. Horizontal bars represent the drug application time. $B$, As in $A$ but fEPSPs were recorded in the presence of $1 \mu \mathrm{m}$ DPCPX. Note that BzATP does not depress fEPSPs under these conditions. C, Summary of the effects of BzATP on mossy fiber fEPSPs in the absence $(n=4)$ or presence $(n=3)$ of DPCPX (1 $\mu \mathrm{M})$.

sion, then it should also lead to activation of postsynaptic adenosine receptors. Postsynaptic adenosine receptors on hippocampal pyramidal cells are coupled to G-protein-gated inwardly rectifying potassium (GIRK) channels (Luscher et al., 1997). Indeed, during whole-cell voltage-clamp recordings of CA3 pyramidal neurons, $65 \mu \mathrm{M}$ BzATP-induced an outward current of $26 \pm 2 \mathrm{pA}\left(V_{\mathrm{h}}=-65 \mathrm{mV} ; n=2\right.$; data not shown $)$. Because the enzymatic conversion of ATP to adenosine and the consecutive activation of adenosine-coupled GIRK channels has been characterized in great detail in CA1 pyramidal cells (Dunwiddie et al.,
A
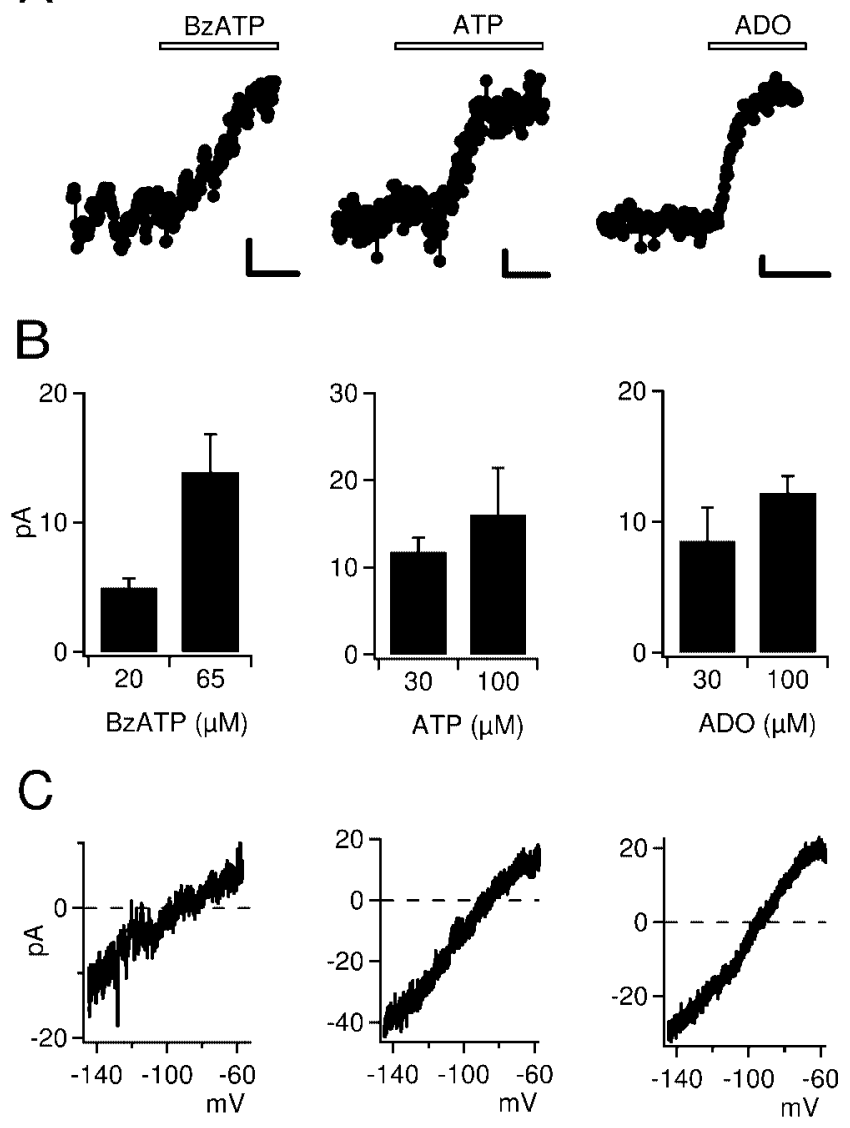

Figure 2. BzATP mimics the activation of potassium conductances by adenosine in hippocampal CA1 pyramidal neurons. $A$, Time course of holding currents in three representative CA1 pyramidal cells during whole-cell recordings $\left(V_{\mathrm{h}}=-65 \mathrm{mV}\right)$. Bath application of BzATP $(65 \mu \mathrm{M}), \operatorname{ATP}(100 \mu \mathrm{M})$, or adenosine (AD0) $(100 \mu \mathrm{M})$ consistently induced a persistent outward current. Holding current was monitored every $2 \mathrm{sec}$. Calibration: 2 pA, 2 min. B, Summary bar graphs showing the outward current amplitude induced by BzATP, ATP, and adenosine $\left(V_{\mathrm{h}}=-65 \mathrm{mV}\right)$. C, Current-voltage (I-V) relationship of BzATP-, ATP-, and adenosineinduced currents. I $V$ curves were recorded in the presence and absence of $65 \mu \mathrm{m}$ BzATP (left), $100 \mu \mathrm{m}$ ATP (middle), or $100 \mu \mathrm{m}$ adenosine (right) in response to voltage ramps from -50 to $-140 \mathrm{mV}, 1 \mathrm{sec}$ duration. The $I-V$ curves shown were calculated as the difference between the $I-V$ curves before and after addition of the agonist. Note that all currents reverse around the potassium equilibrium potential.

1997; Luscher et al., 1997; Takigawa and Alzheimer, 2002), we further studied the effects of BzATP in the CA1 region. In CA1 pyramidal cells, bath application of BzATP also elicited a clear concentration-dependent outward current of $5 \pm 0.7 \mathrm{pA}(n=$ $26)$ and $14 \pm 3 \mathrm{pA}(n=8)$ at 20 and $65 \mu \mathrm{M}$, respectively (Fig. $2 A, B$, left panels). Currents recorded in response to voltage ramps before and during superfusion of the drug revealed that the BzATP current reversed around the potassium equilibrium potential ( $-93 \pm 4 \mathrm{mV} ; n=8$ ) (Fig. 2C, left panel), as expected for GIRK channels (Luscher et al., 1997). In agreement with a previous report (Dunwiddie et al., 1997), the observed currentresponse was mimicked by ATP and adenosine. ATP induced a concentration-dependent outward current of $12 \pm 1.6 \mathrm{pA}$ (30 $\mu \mathrm{M} ; n=12)$ and $16 \pm 5 \mathrm{pA}(100 \mu \mathrm{M} ; n=5)\left(V_{\mathrm{h}}=-65 \mathrm{mV}\right)$ that reversed at $-90 \pm 4 \mathrm{mV}(n=3)$ (Fig. $2 A-C$, middle panels). Similarly, adenosine elicited an outward current of $9 \pm 3 \mathrm{pA}$ $(n=9)$ and $12 \pm 1 \mathrm{pA}(n=14)$ at 30 and $100 \mu \mathrm{M}$, respectively $\left(V_{\mathrm{h}}=-65 \mathrm{mV}\right)$, that reversed at $-93 \pm 6 \mathrm{mV}(n=4)$ (Fig. $2 A-C$, right panels). 


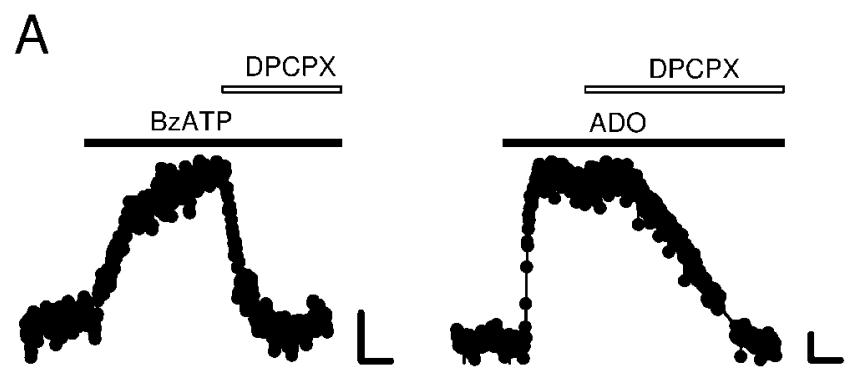

B
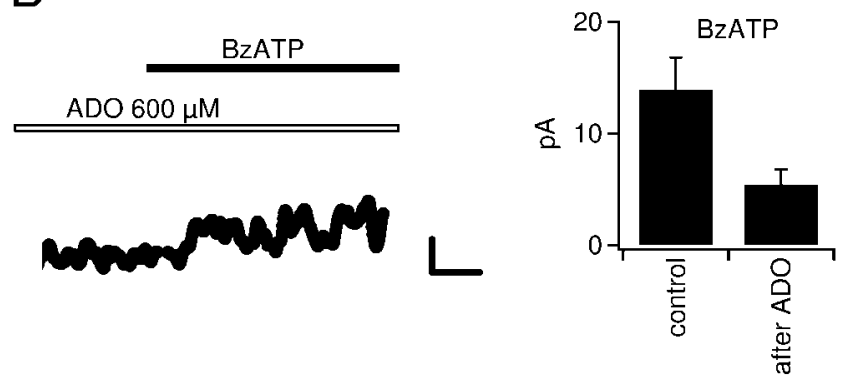

C

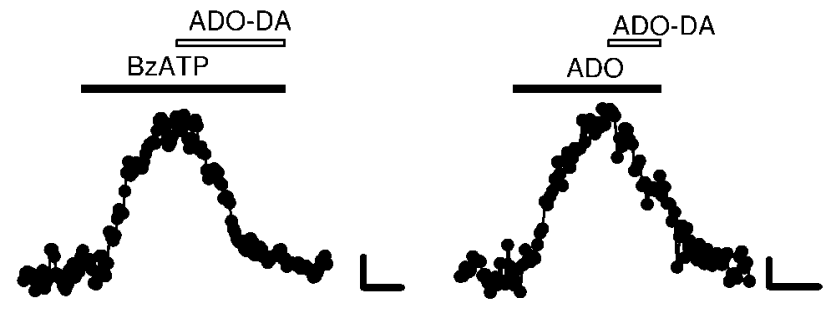

Figure 3. Potassium currents activated by BzATP are mediated by $A_{1}$ receptors and by adenosine. $A$, Responses to $65 \mu \mathrm{m}$ BzATP (left) and $100 \mu \mathrm{m}$ adenosine (right) were completely antagonized by bath superfusion of $0.5 \mu \mathrm{m}$ DPCPX. Calibration: $2 \mathrm{pA}, 2 \mathrm{~min}$. B, Left, Preapplication of a high concentration of adenosine $(600 \mu \mathrm{M})$ occluded the current elicited by $65 \mu \mathrm{M}$ BzATP. Right, Summary bar graph of the outward current induced by BzATP (Bz) without $(n=$ 8 ) or with $(n=4)$ preapplication of adenosine. Calibration: 2 pA, 2 min. C, Coapplication of adenosine deaminase $(2 \mathrm{U} / \mathrm{ml})$ resulted in a complete reversal of the outward current evoked by $65 \mu \mathrm{m}$ BzATP (left) or $100 \mu \mathrm{m}$ adenosine (right) ( $n=4$ and $n=3$, respectively). DPCPX application per se did not cause any significant change in holding current $(n=3$; data not shown). Calibration: 2 pA, 5 min.

We next tested whether BzATP-induced potassium currents are mediated by adenosine receptors as well. Indeed, BzATP-, adenosine-, and ATP-evoked potassium currents were completely reversed by $500 \mathrm{nM}$ of the $\mathrm{A}_{1}$ receptor antagonist DPCPX (Fig. $3 A$ ) ( $n=9$ and $n=17$, respectively). In some cases, $1-3 \mu \mathrm{M}$ DPCPX was applied to speed up the reversal of the current. Adenosine occluded, to a large extent, the increase in potassium conductance induced by BzATP: partial saturation of adenosine receptors by preapplication of a high concentration $(600 \mu \mathrm{M})$ of adenosine significantly reduced the BzATP $(65 \mu \mathrm{M})$-induced current to $5.4 \pm 1.4 \mathrm{pA}(n=4)$ (Fig. $3 B)$. A similar outward current was recorded when $65 \mu \mathrm{M}$ adenosine was added after preapplication of a high adenosine concentration $(300-600 \mu \mathrm{M} ; 4.9 \pm 0.4$ $\mathrm{pA} ; n=4$; data not shown). Moreover, coperfusion of slices with adenosine deaminase $(2 \mathrm{U} / \mathrm{ml})$, an enzyme that converts adenosine (and 2'-deoxyadenosine) to its inactive metabolite inosine (and 2'-deoxyinosine) (Cristalli et al., 2001), resulted in a complete reversal of the current evoked either by BzATP or by adenosine (Fig. 3C). Taken together, our experiments suggest that the responses of hippocampal neurons to BzATP are mediated by adenosine acting at adenosine $A_{1}$ receptors.

BzATP is converted to adenosine by a combined action of ecto-nucleotidases and nucleoside transporters

To directly assess whether BzATP, in analogy to ATP, is catabolized via the ecto-nucleotidase pathway, we used specific inhibitors of the involved enzymes. The first reaction of hydrolysis of ATP is catalyzed by ecto-NTPDases (E-NTPDases), a family of enzymes reviewed by Zimmermann (2000). E-NTPDases catabolize ATP to ADP and ATP/ADP to AMP, and they can be inhibited by ARL 67156 (Crack et al., 1995; Westfall et al., 1996, 2000; Mihaylova-Todorova et al., 2002). Consistent with the idea that BzATP is similarly metabolized as ATP before it can activate GIRK channels, ARL 67156 abolished BzATP-induced currents (Fig. $4 A, D)(n=4)$. Importantly, adenosine was still active, showing that the function of $A_{1}$ receptors is not affected by ARL 67156 (Fig. $4 A)(n=4)$. Likewise, when the E-NTPDase substrate ITP was added in excess $(2 \mathrm{mM}$ ) to competitively reduce the hydrolysis, the current activated by BzATP but not that activated by adenosine was blocked (Fig. $4 B, D)(n=5)$. The final step of catabolism of ATP by ecto-nucleotidases is the conversion of AMP to adenosine. This step is catalyzed by ecto-5NTase and can be inhibited by concanavalin A (Stefanovic et al., 1975; Zygowicz et al., 1977; Westfall et al., 2002). To further substantiate the necessity of the ecto-nucleotidase pathway for BzATP to be active, we confirmed that concanavalin A blocked BzATP but not adenosine-induced currents (Fig. $4 C, D)(n=4)$.

Coperfusion of an adenosine-specific deaminase (Cristalli et al., 2001) reversed the outward current caused by BzATP (Fig. 3). This indicates that when BzATP is superfused, it is adenosine that activates GIRK-coupled $A_{1}$ receptors; however, in contrast to the hydrolyzation of ATP, the hydrolyzation of BzATP should only give rise to $\mathrm{Bz}$-adenosine and not adenosine itself (see Discussion). We therefore asked whether nucleoside transporters (NTrans) could hetero-exchange extracellular Bz-adenosine for adenosine from intracellular sources (compare Fig. 9). Various types of NTrans systems are present in the brain, which is deficient of de novo synthesis of nucleotides (Pastor-Anglada et al., 1998; Lee et al., 2001). For this reason, NTrans are essential for the salvage of nucleosides for nucleotide and nucleic acid synthesis in the brain (Lee et al., 2001). Inosine is a substrate of a large number of such NTrans and has frequently been used to competitively inhibit their transport activity (Yao et al., 1997; PastorAnglada et al., 1998; Li et al., 2001). Indeed, outward current induced by BzATP $(30 \mu \mathrm{M})$ was reversed when we added $2 \mathrm{~mm}$ inosine to the superfusion medium $(n=6)$ (Fig. $4 E$ ). As mentioned above, enzymatic conversion of ATP leads directly to formation of adenosine. Thus, activation of GIRK channels by ATP should not be sensitive to the inhibition of NTrans by coapplication of inosine. In support of this idea, $2 \mathrm{~mm}$ inosine did not decrease ATP-induced outward current $(n=6)$ (Fig. $4 F)$, which also shows that the function of ecto-nucleotidases and $\mathrm{A}_{1}$ receptors is unaffected by inosine.

It has been suggested previously that the depression of mossy fiber synaptic transmission by BzATP involves activation of a MAP kinase (Armstrong et al., 2002). The key experiment that led the authors to that conclusion was that the presumed specific $\mathrm{p} 38$ MAP kinase inhibitor SB 203580 blocked BzATP-induced depression of fEPSPs, whereas it did not affect the adenosine receptor-mediated depression of synaptic transmission (Armstrong et al., 2002). There could be an alternative explanation, however, for the differential blocking effect of SB 203580: SB 


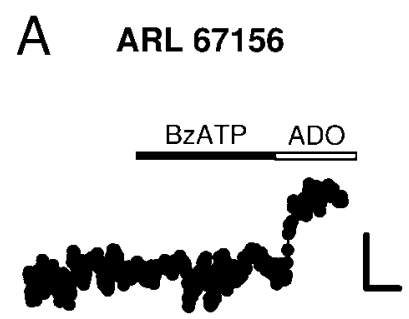

C $\operatorname{Con} \mathrm{A}$

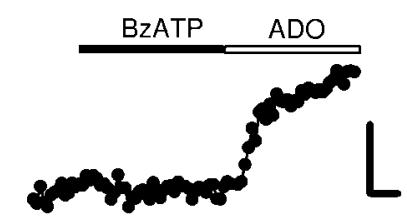

E

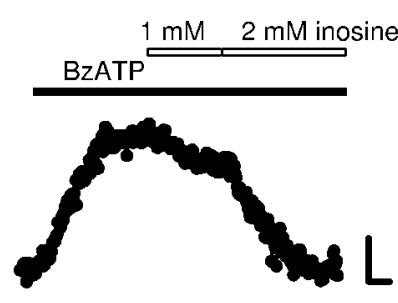

G

SB 203580
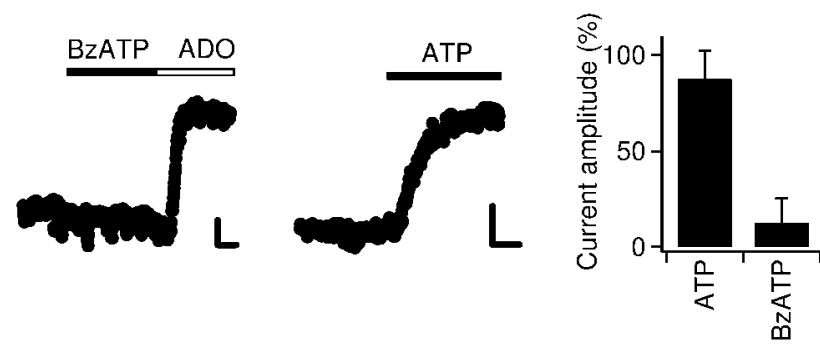

Figure 4. Inhibition of ecto-nucleotidases or nucleoside transporters blocks the responses to BzATP. A, Preincubation of hippocampal slices with $100 \mu \mathrm{m}$ ARL 67156 for $45-60$ min resulted in a complete inhibition of BzATP-induced current $(20 \mu \mathrm{M})$. Importantly, the response to adenosine (100 $\mu \mathrm{M})$ was unchanged. Calibration: 5 pA, 2 min. B, As before but slices were preincubated with $2 \mathrm{~mm}$ ITP (adenosine, $100 \mu \mathrm{M}$ ). C, As in A but slices were incubated with $8 \mathrm{~mm}$ concanavalin A monomers (adenosine, $30 \mu \mathrm{M}$ ). D, Summary bar graph of experiments with ecto-nucleotidase inhibitors. The mean current amplitudes evoked by BzATP under the four different conditions were divided by the mean current amplitude obtained under control conditions (20 $\mu \mathrm{m}$ BzATP) (compare Fig. $1 B$ ) and multiplied by 100\%. E, The NTrans substrate inosine $(2 \mathrm{~mm})$ reverses the response to $65 \mu \mathrm{m}$ BzATP. F, Inosine $(2 \mathrm{~mm})$ does not decrease the outward current induced by $30 \mu \mathrm{m}$ ATP. In fact, in three of six experiments it increased the current amplitude. This increase most likely reflects increased accumulation of extracellular adenosine when NTrans are bound by inosine. G, SB 203580 mimics the effect of inosine. Preincubation of slices with SB $203580(25 \mu \mathrm{M})$, a purported specific MAP kinase inhibitor, resulted in complete abolishment of BzATP-activated potassium current, whereas adenosine (100 $\mu \mathrm{M})$ and ATP-induced currents were nearly undiminished. Summary bar graph (right) shows the fractions of the BzATP-and ATP-induced currents that remain after preincubation in SB 203580.
A

B
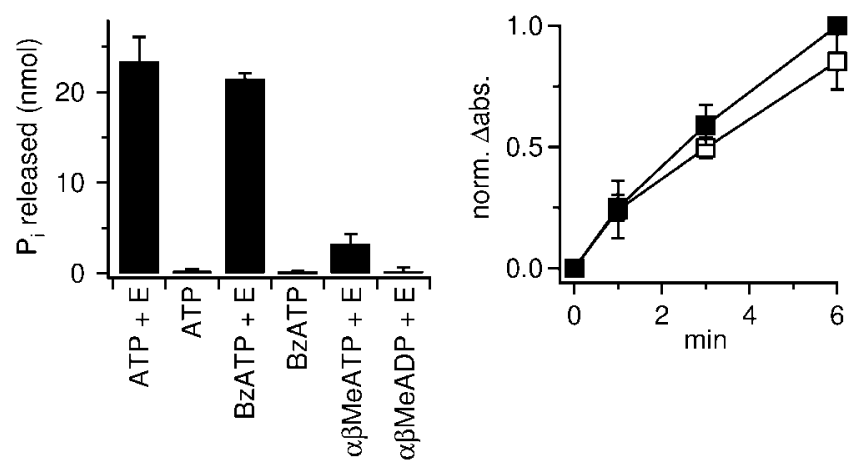

Figure 5. BzATP is hydrolyzed in vitro by E-NTPDase and E-5NTase. $A$, Incubation of ATP, BzATP, $\alpha, \beta$-MeATP, or $\alpha, \beta$-Me-ADP with the enzymes in vitro resulted in accumulation of $\mathrm{P}_{\mathrm{i}}$. Note that an identical amount of $P_{i}$ was released from ATP and BzATP. Without enzymes $(E)$, only negligible amounts of $\mathrm{P}_{\mathrm{i}}$ were detected. Incubation of $\alpha, \beta$-MeATP yielded only a small amount of $\mathrm{P}_{\mathrm{i}}, \alpha, \beta$-MeADP was resistant to hydrolysis. $B$, Time course of $\mathrm{P}_{\mathrm{i}}$ release from ATP ( $\square$ ) and BzATP $(\square)$ during the incubation of these adenine nucleotides with ecto-nucleotidases. The reactions were started in parallel and stopped successively after 1,3, and 6 min. Enzymatic activity and $\mathrm{Ca}^{2+}$ concentration were strongly decreased to reduce the reaction rate. After 1 min, only a small portion of substrates has been hydrolyzed, and $>6$ min would be required under those conditions to achieve equilibrium. Note that the initial accumulation of $P_{i}$, being proportional to the initial reaction velocity, is similar for BzATP and ATP. Absorption values were normalized in each run on the absorption value of the ATP vial that was incubated for 6 min (norm. $\Delta$ abs.).

203580 has recently be shown to block NTrans (Huang et al., 2002). If SB 203580 blocked NTrans in hippocampal slices, adenosine would not be released in the presence of SB 203580, and consequently the BzATP-induced depression of mossy fiber transmission would be prevented. On the contrary, bath application of adenosine would still reduce synaptic transmission in the presence of SB 203580. This scenario predicts that SB 203580 should block the activation of GIRK channels by BzATP but not that by ATP. Indeed, when we treated slices with SB 203580 according to the protocol used by Armstrong et al. (2002), the activity of BzATP was potently suppressed (to $13 \pm 13 \% ; n=4$ ) (Fig. 4G, left and right panels), whereas the current evoked by ATP was hardly affected ( $88 \pm 15 \% ; n=5$ ) (Fig. $4 G$, middle and right panels).

\section{BzATP is a substrate of ecto-nucleotidases in vitro}

We tested whether enzyme activities known to be present in hippocampal slices (members of the E-NTPDase family and 5NTase) (Cunha et al., 1992, 1998, 2000; Braun et al., 2000; Boeck et al., 2002; Bruno et al., 2002) hydrolyze BzATP in vitro. For this purpose we incubated $15 \mathrm{nmol}$ of substrates with purified enzymes $(2 \mathrm{U} / \mathrm{ml}$ NTPDase and $2 \mathrm{U} / \mathrm{ml} 5 \mathrm{NT}$ ase, $40 \mathrm{~min}$ ) in the presence of $2 \mathrm{mM} \mathrm{Ca}^{2+}$. After incubation we determined the concentration of free phosphate $\left(\mathrm{P}_{\mathrm{i}}\right)$. Under these conditions the enzymes released $23 \pm 2 \mathrm{nmol}_{\mathrm{i}}(n=5)$ (Fig. 5A) from ATP. As expected, we found an identical amount of $\mathrm{P}_{\mathrm{i}}(22 \pm 4 \mathrm{nmol} ; n=$ 5) (Fig. 5A) after incubation of BzATP with the enzymes. To compare the profile of enzymatic activity of our in vitro system with that of hippocampal slices, we tested two additional ATP analogs: $\alpha \beta$-MeATP and $\alpha \beta$-MeADP. Hippocampal slices can only remove the terminal $\mathrm{P}_{\mathrm{i}}$ from $\alpha \beta$-MeATP, yielding $\alpha \beta$ MeADP (Cunha et al., 1998). The latter cannot be hydrolyzed further and acts as an ecto-nucleotidase inhibitor (Dunwiddie et al., 1997; Cunha et al., 1998). In agreement with those reports, incubation of enzymes with $\alpha \beta$-MeATP led to an accumulation 
of $3.3 \pm 0.6 \mathrm{nmol} \mathrm{P}_{\mathrm{i}}$ only $(n=6)$, but $\alpha \beta$-MeADP was completely resistant to enzymatic breakdown (Fig. $5 A$ ).

The above experiments demonstrate that BzATP is a substrate of NTPDase/5NTase; however, because reactions were run until steady state, it is not possible to infer from that data whether there is a preferential hydrolysis of ATP versus BzATP. As a rough test of the apparent affinity of the enzymes for ATP versus BzATP, we compared the respective initial reaction velocities. We slowed down the reaction by decreasing enzyme activity $(0.2 \mathrm{U} / \mathrm{ml}$ each $)$ and $\mathrm{Ca}^{2+}$ concentration $(0.02 \mathrm{~mm})$ in the incubation buffer to minimize the reduction in initial substrate concentration. Reactions were stopped at various time points with EDTA. After $1 \mathrm{~min}$ reaction time, the amount of $\mathrm{P}_{\mathrm{i}}$ released from ATP and BzATP was nearly identical (Fig. $5 B$ ), suggesting that the enzymes have a similar affinity for both substrates.

Given that SB 203580 inhibits p38 MAP kinase by occupation of its ATP binding site (Young et al., 1997), we speculated that SB 203580 interferes with the binding of BzATP or ATP to E-NTPDases as well. For this reason we checked whether SB 203580 inhibits the hydrolysis of nucleotides in our in vitro assay; however, the amount of phosphate released from ATP in the presence of SB 203580 was $101 \pm 9 \%(n=7)$ when normalized on the amount of phosphate released in control vials run in parallel without SB 203580. Similarly the catabolism of BzATP was unchanged by the presence of SB 203580 (97 $\pm 7 \% ; n=4)$. Thus, in agreement with the above finding that adenosine- and ATPinduced currents are unaffected by SB 203580, the catabolism of nucleotides appears to be unaffected by SB 203580 .

\section{BzATP does not increase $\left[\mathrm{Ca}^{2+}\right]_{\mathrm{i}}$ levels in mossy fiber terminals}

The data so far demonstrate that BzATP is hydrolyzed by hippocampal slices and that the reported effects of this drug can be explained by activation of $\mathrm{A}_{1}$ receptors instead of $\mathrm{P} 2 \mathrm{X}_{7}$ receptors; however, two recent studies using (the same) antibodies directed against $\mathrm{P}_{2} \mathrm{X}_{7}$ described strong labeling of mossy fibers terminals (Armstrong et al., 2002; Sperlagh et al., 2002). Thus the question arises whether $\mathrm{P} 2 \mathrm{X}_{7}$ receptors can possibly be activated by BzATP when enzymatic breakdown is inhibited. Our aforementioned experiments have revealed that ITP is a useful tool to prevent the breakdown of BzATP (Fig. 4).

It is well known that $\mathrm{P} 2 \mathrm{X}_{7}$ receptors are $\mathrm{Ca}^{2+}$ permeable and that in the continuous presence of the agonist $(>5 \mathrm{~min})$, this channel typically forms a large-conductance pore through which even molecules with a molecular weight up to $900 \mathrm{Da}$ can pass (Steinberg et al., 1987; Michel et al., 1999; North, 2002). Therefore, activation of $\mathrm{P} 2 \mathrm{X}_{7}$ should lead to an increase of intracellular $\mathrm{Ca}^{2+}$ concentration, and this increase has been used in many studies to assess the function of this receptor subtype (Schilling et al., 1999; Naemsch et al., 2001; James and Butt, 2002; North, 2002; Nobile et al., 2003). In the presence of ITP, we tested whether application of BzATP leads to an increase in $\mathrm{Ca}^{2+}$ levels in mossy fiber terminals. Mossy fibers were loaded with the highaffinity $\mathrm{Ca}^{2+}$ indicator Oregon Green-BAPTA-1-AM and imaged with confocal laser microscopy (Fig. 6A). Viability of the presynaptic terminals was assessed by stimulating the fibers and obtaining a clear fluorescence increase that is caused by action potential-induced $\mathrm{Ca}^{2+}$ entry (Fig. 6B). After that, TTX was added to the bath to reduce spontaneous activity. Application of $65 \mu \mathrm{M}$ BzATP for $17 \mathrm{~min}$ did not result in any increase in resting fluorescence (101 $\pm 3 \% ; n=4$; not significant; paired $t$ test), indicating that there was no $\mathrm{P} 2 \mathrm{X}_{7}$-mediated $\mathrm{Ca}^{2+}$ influx (Fig. $6 \mathrm{~A}$, middle, $C$, summary graph). In contrast, we could detect even a

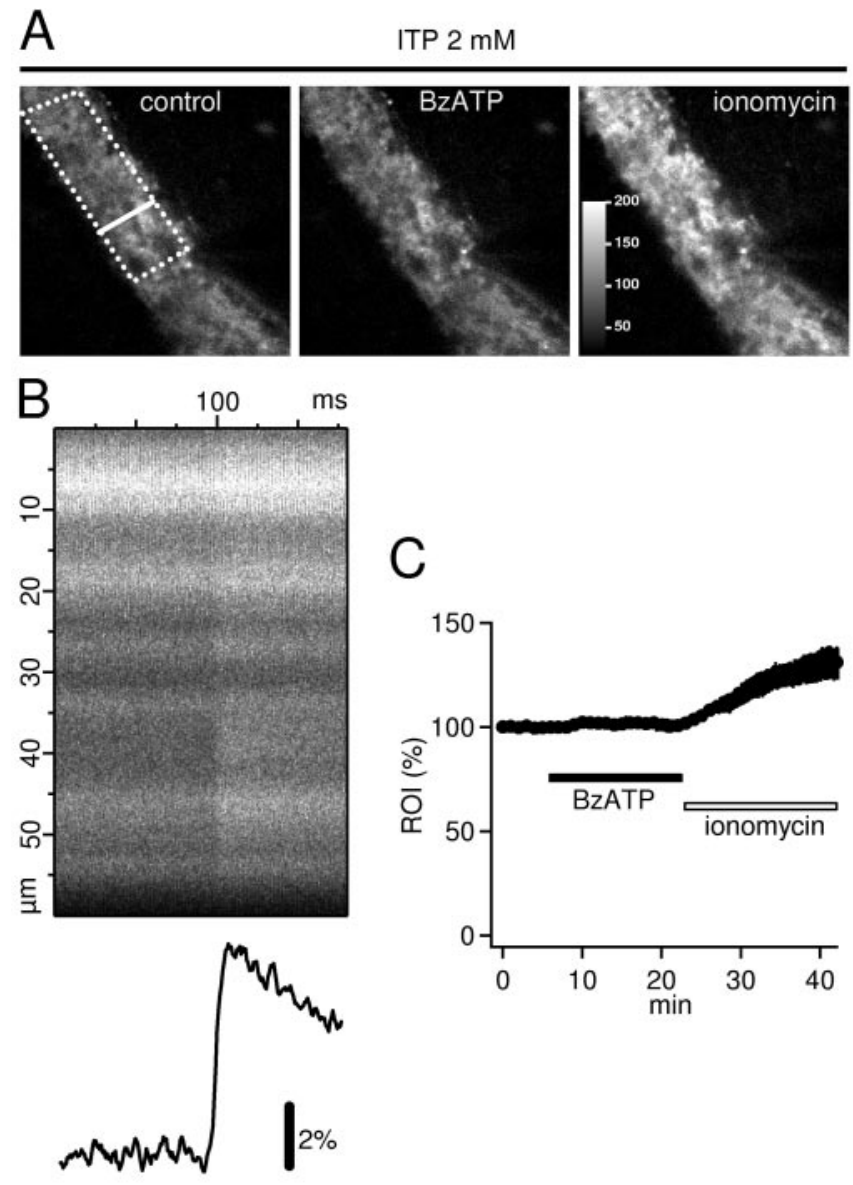

Figure 6. BzATP does not cause an increase in presynaptic $\mathrm{Ca}^{2+}$ of hippocampal mossy fiber terminals. A, Mossy fiber bundle in CA3 stratum lucidum was filled with the high-affinity $\mathrm{Ca}^{2+}$ indicator Oregon Green-BAPTA-1 and visualized using confocal laser scanning microscopy. Dotted line indicates a typical ROl that was used for the analysis of resting $\mathrm{Ca}^{2+}$ shown in C. Bold line represents the position of the line scan that was used to analyze the stimulus-evoked increase in $\mathrm{Ca}^{2+}$ (shown in $B$ ). Bath application of $65 \mu \mathrm{m}$ BzATP in the presence of $0.5 \mu \mathrm{m} \mathrm{TTX}$ and 2 mM ITP did not induce an increase in $\mathrm{Ca}^{2+}$ levels (middle; no change in brightness). In contrast, superfusion of 3-6 $\mu \mathrm{m}$ of the $\mathrm{Ca}^{2+}$ ionophore ionomycin clearly increased intraterminal $\mathrm{Ca}^{2+}$ (right), as evidenced by the brighter terminals. Color scale in the right panel is valid for all three panels, and values represent arbitrary digital units. $B$, Repetitive line scans ( $3 \mathrm{kHz})$ during a single stimulation of mossy fibers reveal a TTX-sensitive increase in presynaptic $\mathrm{Ca}^{2+}$. The $y$-axis denotes the width of the line scan along the bold line shown in $A$ (left panel); $x$-axis indicates the time during repetition of the line scan. Note the sharp fluorescence increase at $\sim 100$ msec. Time-dependent increase in fluorescence averaged across the line scan is shown below. C, Average time course of four experiments as shown in A. BzATP (65 $\mu \mathrm{m})$ caused no elevation of resting $\mathrm{Ca}^{2+}$ in mossy fibers as would be expected for functional $\mathrm{P} 2 \mathrm{X}_{7}$ subunits. The $\mathrm{Ca}^{2+}$ ionophore ionomycin $(3-6 \mu \mathrm{m})$ caused a $30 \%$ increase. Frame scans were acquired every $30 \mathrm{sec}$. The average fluorescence intensity in the ROI were normalized to the average value before BzATP application. Note that error bars (SEM) partially disappear in the symbols.

small elevation in $\mathrm{Ca}^{2+}$ caused by a low concentration of the $\mathrm{Ca}^{2+}$ ionophore ionomycin $(130 \pm 8 \% ; n=4$; statistically significant; paired $t$ test) (Fig. $6 A$, right, $C$, summary graph).

Similar $\mathrm{Ca}^{2+}$ imaging experiments, albeit without ITP, were performed under different conditions that have been shown previously to potentiate $\mathrm{P}_{2} \mathrm{X}_{7}$ function in other preparations (Michel et al., 1999). We reduced the concentration of extracellular divalent cations (down to $0 \mathrm{Mg}^{2+}$ and $1 \mathrm{Ca}^{2+}$ ), substituted sodium (up to $90 \%$ ) with sucrose $(n=5)$, and elevated the recording temperature $\left(35^{\circ} \mathrm{C}\right)$; however, we never observed a $\mathrm{Ca}^{2+}$ increase in mossy fiber terminals on perfusion of BzATP (60-200 $\mu \mathrm{M})$. In an additional series we incubated slices with $0.1 \%$ Lucifer 

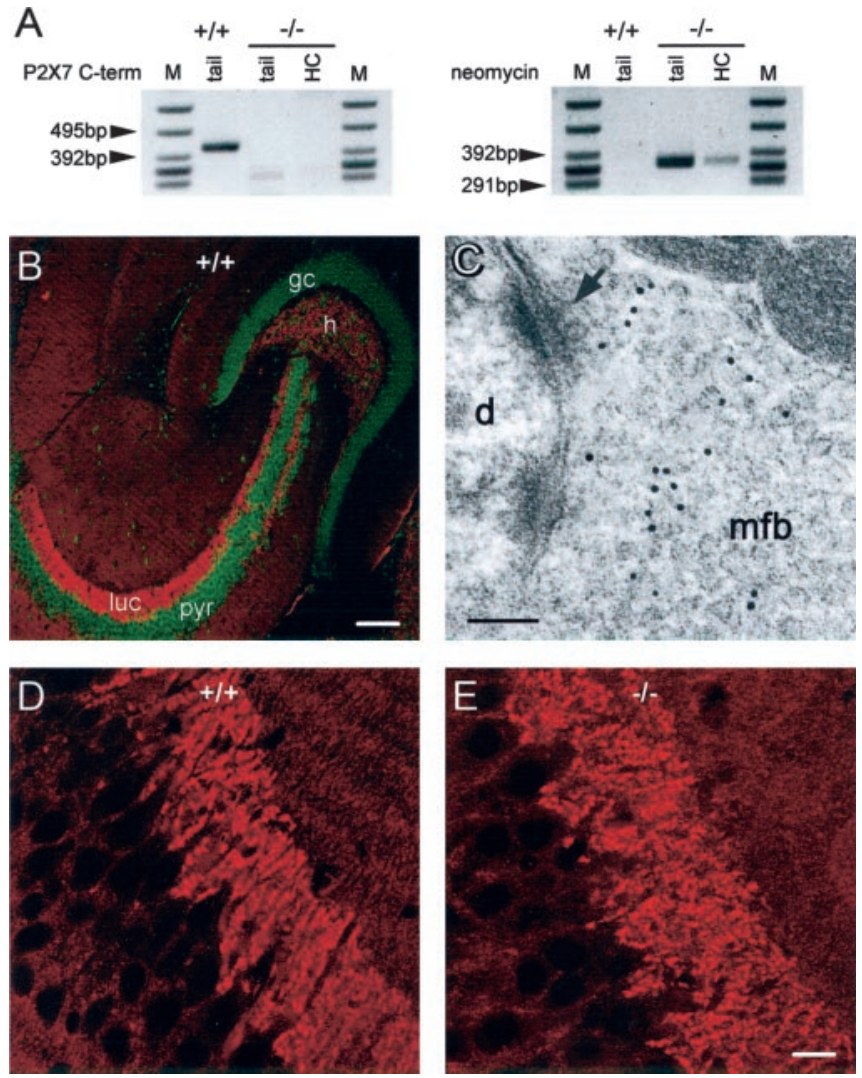

Figure 7. Pseudo-P2X immunoreactivity in rodent hippocampus. $A, P C R$ analysis of DNA extracted from tails and hippocampi of wild-type $(+/+)$ and $\mathrm{P}_{2} \mathrm{X}_{7}{ }^{-1-}(-/-)$ mice to detect the sequence encoding the $C$ terminus of $P 2 X_{7}$ ( $419 \mathrm{bp}$; left blot) or the neomycin resistance gene (343 bp; right blot). $M$, Marker; $H C$, hippocampus. DNA encoding the C terminus is absent from the tail as well as from the hippocampal specimen of $\mathrm{P}_{2} \mathrm{X}_{7}{ }^{-1-}$ mice but present in tissue from wild-type mice (left panel). Conversely, the neomycin resistance gene was absent from wild-type mice but present in hippocampi and tails from $\mathrm{P}_{2} \mathrm{X}_{7}{ }^{-1-}$ mice (right panel). $B, \mathrm{Im}$ munohistochemistry with antibodies directed to $\mathrm{P} 2 \mathrm{X}_{7}$ revealed dense labeling (red) throughout mossy fiber termination zones in the dentate hilus (h) and stratum lucidum (luc). pyr, Stratum pyramidale of CA3; gc, dentate granule cells. Green color represents a nuclear counterstain.

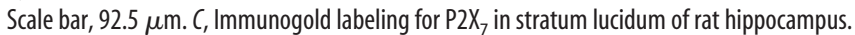
Labeling is associated with vesicles but not with the presynaptic membrane. mfb, Mossy fiber bouton; arrow indicates synaptic junction with an opposing postsynaptic density; $d$, dendrite. Magnification, $174.600 \times$. Scale bar, $0.1 \mu \mathrm{m}$. D, High-power view of $\mathrm{P} 2 \mathrm{X}_{7}$ antibody labeling in the stratum lucidum of a wild-type mouse. Black holes correspond to cell bodies of CA3 pyramidal cells. Labeling is strongest in the area of stratum lucidum. Black lines through stratum lucidum represent dendrites of pyramidal cells that separate mossy fiber boutons. $E$, Highpower view of $\mathrm{P} 2 \mathrm{X}_{7}$ antibody labeling in the stratum lucidum of a $\mathrm{P} 2 \mathrm{X}_{7}{ }^{-1-}$ mouse. No difference in immunoreactivity was observed between wild-type and $\mathrm{P}_{2} \mathrm{X}_{7}{ }^{-1-}$ mice $(D)$. Scale bar, $15.4 \mu \mathrm{m}$.

yellow and BzATP $(n=4)$, but again we never observed uptake of the dye into mossy fiber terminals or any other neuronal structure in the hippocampus.

\section{P2X $\mathrm{X}_{7}$ immunoreactivity and BzATP effect on synaptic transmission in mice lacking $\mathrm{P} 2 \mathrm{X}_{7}$ receptors}

As mentioned above, immunohistochemistry with commercial anti-P2 $\mathrm{X}_{7}$ antibodies (Alomone Labs) revealed strong labeling of mossy fiber terminals in the hippocampus (Armstrong et al., 2002; Sperlagh et al., 2002). Using the same antibodies, we could reproduce the reported staining pattern in both mouse (Fig. $7 B$ ) and rat (data not shown) hippocampus. As illustrated in Figure 7, $B$ and $D$, confocal laser scanning microscopy revealed dense immunoreactive terminals throughout the mossy fiber termination zone in the hilus and in stratum lucidum of CA3. Fainter staining was also observed throughout the hippocampus (with the exception of cell bodies). To test the specificity of antibody binding, we stained brain slices from $\mathrm{P} 2 \mathrm{X}_{7}$-deficient mice $\left(\mathrm{P} 2 \mathrm{X}_{7}{ }^{-1-}\right.$ mice) using the same protocol. In one strain of $\mathrm{P}_{2} \mathrm{X}_{7}{ }^{-1-}$ mice, the part of the receptor that is recognized by the antibody, the $\mathrm{C}$ terminus (Alomone Labs), has been deleted (Solle et al., 2001). PCR analysis of DNA samples extracted from tail and hippocampal tissue confirmed the absence of the DNA sequence encoding for the $\mathrm{C}$ terminus in our strain of $\mathrm{P}_{2} \mathrm{X}_{7}{ }^{-1-}$ mice (Fig. 7A). Still, despite the absence of this antigen, the staining of hippocampal mossy fiber terminals was completely unchanged in $\mathrm{P}_{2} \mathrm{X}_{7}{ }^{-1-}$ mice (Fig. $7 E)$. To verify this finding, we stained another strain of $\mathrm{P}_{2} \mathrm{X}_{7}^{-l-}$ mice in which the receptor knock-out has been performed by a frame shift (Sikora et al., 1999). Similarly, immunostaining of the mossy fiber termination zone was not altered when compared with wild-type mice (data not shown). We further investigated the subcellular distribution of antibody binding using immunogold labeling and electron microscopy (Fig. 7C). Gold grains were predominantly seen between and on the vesicles of mossy fiber boutons but encountered only rarely near the presynaptic membrane (Fig. 7C). Thus the subcellular distribution of this antigen is not compatible with a plasmalemmal receptor that can be activated by extracellular nucleotides.

To substantiate our finding that $\mathrm{P} 2 \mathrm{X}_{7}$ does not contribute to BzATP-mediated depression of synaptic transmission in the mossy fiber pathway, we studied the effect of BzATP on mossy fiber fEPSPs in $\mathrm{P}_{2} \mathrm{X}_{7}{ }^{-1-}$ mice (both strains). As expected, bath application of BzATP $(65 \mu \mathrm{M})$ clearly inhibited the fEPSPs in $\mathrm{P}_{2} \mathrm{X}_{7}{ }^{-1-}$ mice as in wild-type mice: fEPSP amplitudes were reduced by $44 \pm 5 \%$ (Fig. $8 A)(n=3)$. Also, the action of BzATP was reversed by application of DPCPX (Fig. $8 A$ ), and BzATPinduced depression was completely abolished if DPCPX $(1 \mu \mathrm{M})$ was preapplied to the slices (Fig. $8 B, C)(n=3$; $p<0.005)$.

\section{Discussion}

In this study, we reassessed the suggested role of presynaptic $\mathrm{P} 2 \mathrm{X}_{7}$ receptors in depressing glutamate release at the hippocampal mossy fiber-CA3 synapse (Armstrong et al., 2002). Our main findings are that there is no evidence for $\mathrm{P} 2 \mathrm{X}_{7}$ receptors on mossy fiber terminals and the widely used (nonselective) $\mathrm{P} 2 \mathrm{X}_{7}$ agonist BzATP leads to activation of $A_{1}$ receptors via a novel, previously not recognized pathway: BzATP is enzymatically converted by ecto-nucleotidases and the product is heteroexchanged for adenosine by NTrans in hippocampal slices.

We investigated the action of BzATP in detail by monitoring the activation of GIRK channels in whole-cell voltage-clamp recordings. Enzymatic activity of ecto-nucleotidases was necessary for activation of $A_{1}$-coupled GIRK channels after perfusion of BzATP (Fig. 4). This finding and our in vitro assay (Fig. 5) indicate that the phosphate groups of BzATP can be hydrolyzed by ecto-nucleotidases present in hippocampal slices. A very similar catabolism by ecto-enzymes in hippocampal slices has been described for ATP and ATP analogs (Dunwiddie et al., 1997; Cunha et al., 1998).

A number of our results demonstrate that application of BzATP onto hippocampal slices leads to activation of $A_{1}$ receptors. (1) BzATP mimics the depression of mossy fiber synaptic transmission by $\mathrm{A}_{1}$ receptors (Okada and Ozawa, 1980; Scanziani et al., 1992) (Fig. 1). (2) It mimics the activation of GIRK channels on CA3 and CA1 neurons, respectively (Luscher et al., 1997) (Fig. 2). (3) All effects of BzATP could be reversed by the selective $\mathrm{A}_{1}$ receptor antagonist DPCPX (Lohse et al., 1987) (Figs. 1, 3, 8). 


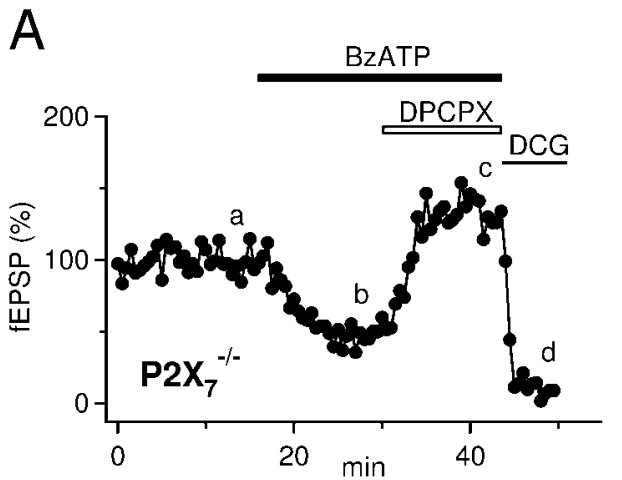

B

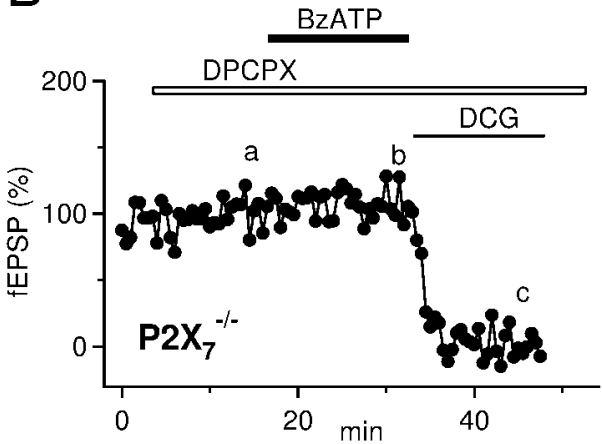

C

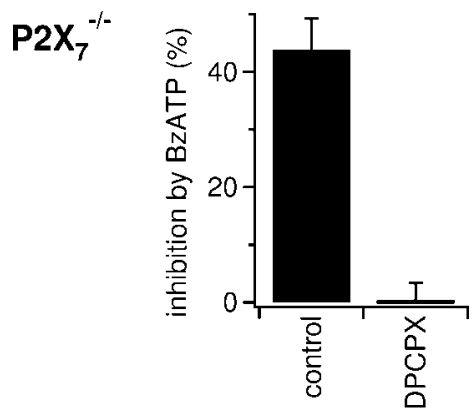

Figure 8. Inhibition of mossy fEPSPs by BzATP $(65 \mu \mathrm{m})$ is unchanged in P2X ${ }_{7}^{-1-}$ mice. $A$, Time course of fEPSP amplitude and example traces from time points are indicated by lowercase letters. DPCPX $(1 \mu \mathrm{m})$ reverses the depression of fEPSPs by BzATP $(65 \mu \mathrm{m})$. Horizontal bars represent the drug application time. Compare with Figure $1 A$. $B$, As in $A$ but fEPSPs were recorded in the presence of $1 \mu \mathrm{m}$ DPCPX. Note that BzATP does not depress fEPSPs under these conditions. C, Summary of the effects of BzATP on mossy fiber fEPSPs in the absence $(n=4)$ or presence $(n=3)$ of DPCPX (1 $\mu \mathrm{m})$.

It should be noted, however, that the concentration of DPCPX used in our study $(300 \mathrm{nM}-1 \mu \mathrm{M})$ is not specific for $A_{1}$ receptors but can also antagonize $A_{2 B}$ receptors (Fredholm et al., 2001). In light of the previous studies and the very rapid onset of the DPCPX effect, however, $A_{1}$ receptors appear to be the most likely candidates mediating the actions of BzATP.

Although these experiments suggest the involvement of $A_{1}$ receptors, they do not identify the ligand that binds to the receptors. In contrast to the catabolism of ATP, dephosphorylation of BzATP should produce Bz-adenosine and not adenosine, because the benzoyl-benzoyl group is attached to $\mathrm{C}_{3}$ of the ribose and therefore will not be removed together with the phosphates (Fig. 9 ). On the other hand, for this modified ribose, Bz-adenosine is unlikely to be a potent $A_{1}$ receptor agonist (van Galen et al., 1994;
A

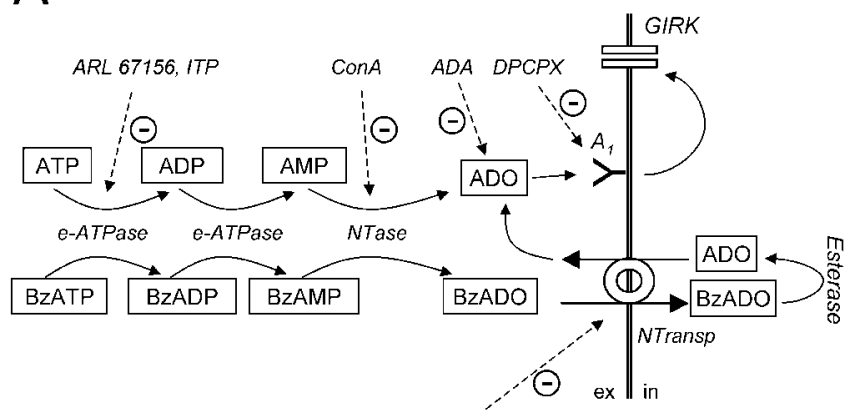

inosine, SB 203580

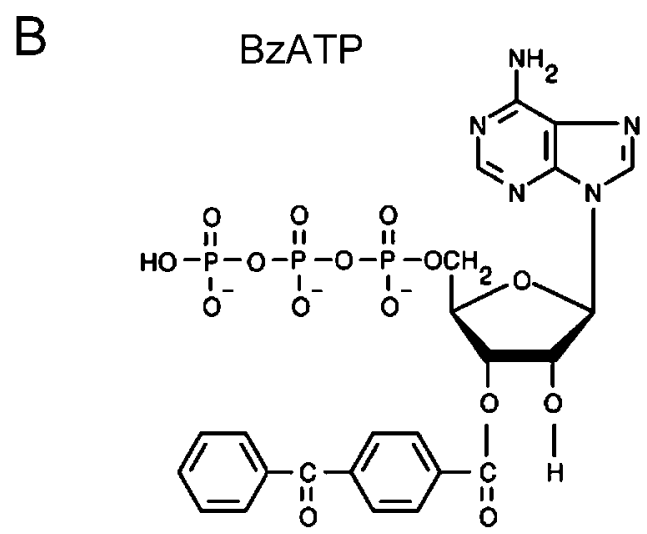

Figure 9. Hypothetical scheme to explain the $A_{1}$ receptor-mediated action of ATP and BzATP in hippocampal slices. $A$, In three steps, ATP and BzATP are converted to adenosine and Bzadenosine, respectively. The enzymes involved are E-NTPDases and 5NTase and can be inhibited by ARL 67156, ITP, and concanavalin A. Adenosine deaminase (ADA) metabolizes adenosine. $D P C P X$ competitively inhibits $A_{1}$ receptor activation. Bz-adenosine cannot activate $A_{1}$ receptors and cannot be further metabolized in the extracellular space because of lack of extracellular esterase activity (Satoh and Hosokawa, 1998). Instead, Bz-adenosine is transported intracellularly via NTrans, where it is converted to adenosine. In turn, intracellular accumulated adenosine is released in the extracellular space where it activates $A_{1}$ receptors and is a substrate for ADA (Cristalli et al., 2001). Inosine and SB 203580 inhibit BzATP-induced activation of $A_{1}$ receptors but do not affect the activity of either ATP or adenosine because they suppress only NTrans. Metabolites are placed in squares. Inhibitors and enzymes are printed in italic. Continuous arrows indicate conversion, transport, or positive modulation. Dashed arrows denote inhibition. ex, Extracellular; in, intracellular. $B$, Structure image of BzATP. Note the large benzoyl-benzoyl group, which makes it unlikely that $B z$-adenosine is an $A_{1}$ receptor ligand or an ADA substrate.

Klotz, 2000) or to be a substrate of adenosine deaminase, which degrades adenosine and is inhibited by many adenosine derivates (Cristalli et al., 2001). Despite that, BzATP and adenosine induced GIRK currents of very similar amplitude (Fig. 2), and this effect of BzATP could be completely reversed by coapplication of adenosine deaminase (Fig. 3). We hypothesized that after superfusion of BzATP, adenosine is released from intracellular compartments. Cellular release and uptake of adenosine in the brain are mediated by several types of membranous nucleoside transporters (Hyde et al., 2001; Lee et al., 2001; Baldwin et al., 2004). Recent work has shown that NTrans are expressed and functional in rodent hippocampus (Anderson et al., 1999; Sperlagh et al., 2003). Indeed, challenging NTrans with inosine (Yao et al., 1997; Li et al., 2001) reversed the outward current induced by BzATP (Fig. 4). It is important to note that in contrast to adenosine receptors and adenosine deaminase, nucleoside transporters have a rather broad range of substrate selectivity. They transport the full spectrum of nucleosides and even structurally weakly 
related antiviral drugs (Hyde et al., 2001). Based on the reversal of BzATP current by inosine, we suppose that NTrans mediate a hetero-exchange of $\mathrm{Bz}$-adenosine and adenosine. Once BzATP has been transported intracellularly by NTrans, the benzoylbenzoyl group will removed by the required esterase activity, which is restricted to intracellular compartments (Satoh and Hosokawa, 1998). In turn, adenosine will be released in the extracellular space for equilibration (Fig. 9, scheme).

Additional evidence for the involvement of NTrans in the effects of BzATP stems from our experiments using the p38 MAP kinase inhibitor SB 203580, which was recently shown to potently inhibit NTrans in a culture system (Huang et al., 2002). SB 203580 blocks the inhibition of mossy fiber transmission by BzATP, and for this reason Armstrong et al. (2002) suggested that BzATP activates a MAP kinase-dependent pathway. Involvement of a MAP kinase pathway seems to be unlikely for two reasons. First, we could show that BzATP-induced depression of mossy fiber transmission is caused by activation of $\mathrm{A}_{1}$ receptors (Fig. 3), which inhibit presynaptic $\mathrm{Ca}^{2+}$ channels via $\mathrm{G}_{\mathrm{i} / \mathrm{o}}$-proteins ( $\mathrm{Wu}$ and Saggau, 1997; Kamiya et al., 2002). Second, in our study, SB 203580 also reversed the $A_{1}$-mediated activation of GIRK channels by BzATP, whereas it did not diminish the activation of GIRK channels by adenosine (Fig. 4). Thus, the function of the receptors and the associated downstream cascades $\left(\mathrm{G}_{\mathrm{i} / \mathrm{o}^{-}}\right.$ proteins) (Luscher et al., 1997) are not affected by SB 203580. Rather it appears that SB 203580 hinders the formation of adenosine after perfusion of BzATP. Because SB 203580 specifically decreased the activation of GIRK currents by BzATP but not that caused by ATP and because SB 203580 was inactive in our in vitro assay, SB 203580 cannot be an inhibitor of ecto-nucleotidases. Alternatively, SB 203580 could be an inhibitor of NTrans in hippocampal slices as well. This would explain the differential depression of BzATP versus ATP effects (Fig. 4) and thus represents the most parsimonious explanation of the inhibitory effect of SB 203580.

ITP (2 mM) potently inhibited the activation of GIRK current by BzATP $(20 \mu \mathrm{M})$ (Fig. 4), and we reasoned that this inhibitory action was attributable to competitive antagonism at the binding sites of E-NTPDases; however, ITP is a substrate of E-NTPDases as well, and therefore it will be hydrolyzed to inosine. As above, inosine competes with Bz-adenosine for NTrans binding sites. Bath application of $2 \mathrm{~mm}$ ITP could lead to the formation of sufficient inosine to antagonize the binding of Bz-adenosine to NTrans. Thus, ITP may inhibit the action of BzATP by two means: competitive binding to E-NTPDase (ITP) and competitive binding to NTrans (inosine). In contrast, activation of GIRK channels by ATP does not require NTrans (see above). Therefore, the inhibition of ATP-induced currents by ITP should be caused solely by the decreased catabolism of ATP by E-NTPDases. Indeed, 2 mM ITP reduced the activation of GIRK channels by BzATP more strongly (completely) (Fig. 4) than the activation of GIRK channels by $30 \mu \mathrm{M}$ ATP (to $51 \pm 18 \% ; n=5$; data not shown).

Taken together, we favor the following scenario of BzATPmediated activation of $A_{1}$ receptors (Fig. 9): ecto-nucleotidases catabolize BzATP to Bz-adenosine, which is transported intracellularly via NTrans. Then, intracellular esterases remove the $\mathrm{Bz}$ group, and the accumulating adenosine is released via nucleoside transporters and finally activates extracellular $A_{1}$ receptors. Which particular type of NTrans is involved and whether it is placed on glial, neuronal or endothelial elements needs to be clarified in future studies.

The question remains whether there are functional $\mathrm{P} 2 \mathrm{X}_{7}$ re- ceptors on mossy fiber terminals. Strong $\mathrm{P} 2 \mathrm{X}_{7}$ immunoreactivity of mossy fibers terminals has been reported (Armstrong et al., 2002; Sperlagh et al., 2002), and we could reproduce this staining pattern in both mouse (Fig. 7B) and rat (data not shown) hippocampus using the same antibodies. Depression of mossy fiber synaptic transmission by BzATP, however, was not different between wild-type and $\mathrm{P} 2 \mathrm{X}_{7}{ }^{-1-}$ mice, suggesting that $\mathrm{P} 2 \mathrm{X}_{7}$ function is not involved. On the other hand, it is possible that we did not observe a $\mathrm{P} 2 \mathrm{X}_{7}$-dependent effect because metabolism of BzATP precludes a sufficiently high agonist concentration within the slice. In fact, it was suggested that the catabolism of locally applied ATP is nearly quantitative (Dunwiddie et al., 1997). To exclude this possibility, we tested for functional $\mathrm{P} 2 \mathrm{X}_{7}$ receptors, when ectonucleotidase activity was challenged by ITP (Fig. 6). A widely used and sensitive assay to assess the function of $\mathrm{P} 2 \mathrm{X}_{7}$ receptors is to monitor how intracellular $\mathrm{Ca}^{2+}$ accumulates during opening of the $\mathrm{Ca}^{2+}$-permeable ionotropic $\mathrm{P} 2 \mathrm{X}_{7}$ receptor (Schilling et al., 1999; Naemsch et al., 2001; James and Butt, 2002; North, 2002; Nobile et al., 2003). We adopted this approach by loading mossy fiber terminals with a high-affinity $\mathrm{Ca}^{2+}$ indicator. Despite the use of long application times, BzATP did not elevate $\mathrm{Ca}^{2+}$ in mossy fiber terminals. This finding casts doubts on whether the antigen detected by the putative specific antibodies on mossy fiber terminals (Armstrong et al., 2002; Sperlagh et al., 2002; this study) truly represents $\mathrm{P}_{2} \mathrm{X}_{7}$ protein. We tested the specificity of the antibodies in two different strains of $\mathrm{P}_{2} \mathrm{X}_{7}^{-1-}$ mice. In light of the negative results of the functional assay, it was not too surprising that the antibodies labeled the mossy fiber projection of both strains of mice in exactly the same manner as in wild-type mice (Fig. 7). Moreover, electron microscopy revealed that the detected antigen is not located at the presynaptic cytoplasmic membrane as would be expected for a transmitter gated receptor. Rather, the antigen is associated with intracellular presynaptic vesicles. We observed a similarly clear labeling of the molecular layer of the cerebellar cortex as well as of cerebellar glomeruli (our unpublished observations); however, immunoreactivity in cerebellum was unchanged in knock-out mice as well. Thus, it seems that the antibodies cross-react at certain synapses with a presynaptic non- $\mathrm{P}_{2} \mathrm{X}_{7}$ protein.

Because the modulation of transmitter release was not different between wild-type and $\mathrm{P}_{2} \mathrm{X}_{7}{ }^{-1-}$ mice, our data also indicate that there is no $\mathrm{P}_{2} \mathrm{X}_{7}$-mediated metabotropic (not $\mathrm{Ca}^{2+}$ mediated) action that interferes with synaptic transmission. Our findings are in accordance with the general understanding that this receptor subtype is expressed predominantly in immune cells (Collo et al., 1997), where it is responsible for the release of cytokines (Le Feuvre et al., 2002). Indeed, it seems hard to imagine for what reason synaptic terminals should carry $\mathrm{P} 2 \mathrm{X}_{7}$ receptors that are able to form large cytolytic pores and would induce cell death after activation by the transmitter ATP (Brough et al., 2002; Le Feuvre et al., 2002). On the other hand, on the basis of our data, we cannot completely exclude that in addition to some $\mathrm{P} 2 \mathrm{X}_{7}$-like antigen there are some "true" $\mathrm{P} 2 \mathrm{X}_{7}$ receptors present on mossy fiber terminals that act exclusively on targets that are not involved in synaptic transmission; however, we consider this very unlikely, because in a former study (Kukley et al., 2001) we used another antibody directed against $\mathrm{P}_{2} \mathrm{X}_{7}$ and detected no labeling of the mossy fiber projection at all (our unpublished observation). Because all studies that reported presynaptic $\mathrm{P} 2 \mathrm{X}_{7}$ used the same antibody (raised against residues $576-595$ of rat $\mathrm{P}_{2} \mathrm{X}_{7}$; Alomone Labs, Chemicon, Temecula, CA), it will be interesting to see whether future studies can confirm the presence of presynaptic $\mathrm{P}_{2} \mathrm{X}_{7}$ at other nerve terminals (Deuchars et al., 2001; Miras- 
Portugal et al., 2003; Atkinson et al., 2004; Puthussery and Fletcher, 2004).

In conclusion, the present study demonstrates that the supposedly stable $\mathrm{P}_{2} \mathrm{X}_{7}$ agonist BzATP is enzymatically converted by hippocampal slices before it leads to release of adenosine and activation of adenosine receptors. No evidence could be obtained for a functional role of $\mathrm{P}_{2} \mathrm{X}_{7}$ receptors on mossy fiber terminals. Rather, all effects that were observed after application of BzATP could be explained by the activation of adenosine $A_{1}$ receptors.

\section{References}

Anderson CM, Xiong W, Geiger JD, Young JD, Cass CE, Baldwin SA, Parkinson FE (1999) Distribution of equilibrative, nitrobenzylthioinosinesensitive nucleoside transporters (ENT1) in brain. J Neurochem 73:867-873.

Armstrong JN, Brust TB, Lewis RG, MacVicar BA (2002) Activation of presynaptic P2X7-like receptors depresses mossy fiber-CA3 synaptic transmission through p38 mitogen-activated protein kinase. J Neurosci 22:5938-5945.

Atkinson L, Batten TF, Moores TS, Varoqui H, Erickson JD, Deuchars J (2004) . Differential co-localisation of the P2X7 receptor subunit with vesicular glutamate transporters VGLUT1 and VGLUT2 in rat CNS. Neuroscience 123:761-768.

Baldwin SA, Beal PR, Yao SY, King AE, Cass CE, Young JD (2004) The equilibrative nucleoside transporter family, SLC29. Pflügers Arch 447:735-743.

Boeck CR, Sarkis JJ, Vendite D (2002) Kinetic characterization and immunodetection of ecto-ATP diphosphohydrolase (EC 3.6.1.5) in cultured hippocampal neurons. Neurochem Int 40:449-453.

Brandle U, Guenther E, Irrle C, Wheeler-Schilling TH (1998) Gene expression of the P2X receptors in the rat retina. Brain Res Mol Brain Res 59:269-272.

Brandle U, Zenner HP, Ruppersberg JP (1999) Gene expression of P2Xreceptors in the developing inner ear of the rat. Neurosci Lett 273:105-108.

Braun N, Sevigny J, Robson SC, Enjyoji K, Guckelberger O, Hammer K, Di Virgilio F, Zimmermann H (2000) Assignment of ecto-nucleoside triphosphate diphosphohydrolase-1/cd39 expression to microglia and vasculature of the brain. Eur J Neurosci 12:4357-4366.

Brough D, Le Feuvre RA, Iwakura Y, Rothwell NJ (2002) Purinergic (P2X7) receptor activation of microglia induces cell death via an interleukin-1independent mechanism. Mol Cell Neurosci 19:272-280.

Bruno AN, Bonan CD, Wofchuk ST, Sarkis JJ, Battastini AM (2002) ATP diphosphohydrolase (NTPDase 1) in rat hippocampal slices and effect of glutamate on the enzyme activity in different phases of development. Life Sci 71:215-225.

Castillo PE, Weisskopf MG, Nicoll RA (1994) The role of $\mathrm{Ca}^{2+}$ channels in hippocampal mossy fiber synaptic transmission and long-term potentiation. Neuron 12:261-269.

Chizh BA, Illes P (2001) P2X receptors and nociception. Pharmacol Rev 53:553-568.

Collo G, Neidhart S, Kawashima E, Kosco-Vilbois M, North RA, Buell G (1997) Tissue distribution of the P2X7 receptor. Neuropharmacology 36:1277-1283.

Conquet F (1995) . Inactivation in vivo of metabotropic glutamate receptor 1 by specific chromosomal insertion of reporter gene lacZ. Neuropharmacology 34:865-870.

Crack BE, Pollard CE, Beukers MW, Roberts SM, Hunt SF, Ingall AH, McKechnie KC, IJzerman AP, Leff P (1995) Pharmacological and biochemical analysis of FPL 67156, a novel, selective inhibitor of ecto-ATPase. Br J Pharmacol 114:475-481.

Cristalli G, Costanzi S, Lambertucci C, Lupidi G, Vittori S, Volpini R, Camaioni E (2001) Adenosine deaminase: functional implications and different classes of inhibitors. Med Res Rev 21:105-128.

Cunha RA, Sebastiao AM, Ribeiro JA (1992) Ecto-5'-nucleotidase is associated with cholinergic nerve terminals in the hippocampus but not in the cerebral cortex of the rat. J Neurochem 59:657-666.

Cunha RA, Vizi ES, Ribeiro JA, Sebastiao AM (1996) Preferential release of ATP and its extracellular catabolism as a source of adenosine upon highbut not low-frequency stimulation of rat hippocampal slices. J Neurochem 67:2180-2187.
Cunha RA, Sebastiao AM, Ribeiro JA (1998) Inhibition by ATP of hippocampal synaptic transmission requires localized extracellular catabolism by ecto-nucleotidases into adenosine and channeling to adenosine A1 receptors. J Neurosci 18:1987-1995.

Cunha RA, Brendel P, Zimmermann H, Ribeiro JA (2000) Immunologically distinct isoforms of ecto-5' -nucleotidase in nerve terminals of different areas of the rat hippocampus. J Neurochem 74:334-338.

Denlinger LC, Fisette PL, Sommer JA, Watters JJ, Prabhu U, Dubyak GR, Proctor RA, Bertics PJ (2001) Cutting edge: the nucleotide receptor P2X7 contains multiple protein- and lipid-interaction motifs including a potential binding site for bacterial lipopolysaccharide. J Immunol 167:1871-1876.

Deuchars SA, Atkinson L, Brooke RE, Musa H, Milligan CJ, Batten TF, Buckley NJ, Parson SH, Deuchars J (2001) Neuronal P2X7 receptors are targeted to presynaptic terminals in the central and peripheral nervous systems. J Neurosci 21:7143-7152.

Dietrich D, Kirschstein T, Kukley M, Pereverzev A, von der Brelie C, Schneider T, Beck H (2003) Functional specialization of presynaptic Cav2.3 $\mathrm{Ca}^{2+}$ channels. Neuron 39:483-496.

Dunwiddie TV, Diao L, Proctor WR (1997) Adenine nucleotides undergo rapid, quantitative conversion to adenosine in the extracellular space in rat hippocampus. J Neurosci 17:7673-7682.

Edwards FA, Gibb AJ, Colquhoun D (1992) ATP receptor-mediated synaptic currents in the central nervous system. Nature 359:144-147.

Fredholm BB, IJzerman AP, Jacobson KA, Klotz KN, Linden J (2001) International Union of Pharmacology. XXV. Nomenclature and classification of adenosine receptors. Pharmacol Rev 53:527-552.

Huang M, Wang Y, Collins M, Gu JJ, Mitchell BS, Graves LM (2002) Inhibition of nucleoside transport by p38 MAPK inhibitors. J Biol Chem 277:28364-28367.

Hyde RJ, Cass CE, Young JD, Baldwin SA (2001) The ENT family of eukaryote nucleoside and nucleobase transporters: recent advances in the investigation of structure/function relationships and the identification of novel isoforms. Mol Membr Biol 18:53-63.

Inoue K (1998) The functions of ATP receptors in the hippocampus. Pharmacol Res 38:323-331.

James G, Butt AM (2002) P2Y and P2X purinoceptor mediated $\mathrm{Ca}(2+)$ signaling in glial cell pathology in the central nervous system. Eur J Pharmacol 447:247-260.

Kamiya H, Ozawa S, Manabe T (2002) Kainate receptor-dependent shortterm plasticity of presynaptic $\mathrm{Ca}^{2+}$ influx at the hippocampal mossy fiber synapses. J Neurosci 22:9237-9243.

Kato F, Shigetomi E (2001) Distinct modulation of evoked and spontaneous EPSCs by purinoceptors in the nucleus tractus solitarii of the rat. J Physiol (Lond) 530:469-486.

Khakh BS (2001) Molecular physiology of P2X receptors and ATP signaling at synapses. Nat Rev Neurosci 2:165-174.

Khakh BS, Henderson G (1998) ATP receptor-mediated enhancement of fast excitatory neurotransmitter release in the brain. Mol Pharmacol 54:372-378.

Khakh BS, Bao XR, Labarca C, Lester HA (1999) Neuronal P2X transmittergated cation channels change their ion selectivity in seconds. Nat Neurosci 2:322-330.

Khakh BS, Burnstock G, Kennedy C, King BF, North RA, Seguela P, Voigt M, Humphrey PP (2001) International Union of Pharmacology. XXIV. Current status of the nomenclature and properties of P2X receptors and their subunits. Pharmacol Rev 53:107-118.

Khakh BS, Gittermann D, Cockayne DA, Jones A (2003) ATP modulation of excitatory synapses onto interneurons. J Neurosci 23:7426-7437.

Klotz KN (2000) Adenosine receptors and their ligands. Naunyn Schmiedebergs Arch Pharmacol 362:382-391.

Kukley M, Barden JA, Steinhauser C, Jabs R (2001) Distribution of P2X receptors on astrocytes in juvenile rat hippocampus. Glia 36:11-21.

Lee G, Dallas S, Hong M, Bendayan R (2001) Drug transporters in the central nervous system: brain barriers and brain parenchyma considerations. Pharmacol Rev 53:569-596.

Le Feuvre RA, Brough D, Iwakura Y, Takeda K, Rothwell NJ (2002) Priming of macrophages with lipopolysaccharide potentiates P2X7-mediated cell death via a caspase-1-dependent mechanism, independently of cytokine production. J Biol Chem 277:3210-3218.

Le Mouellic H, Lallemand Y, Brulet P (1990) Targeted replacement of the 
homeobox gene Hox-3.1 by the Escherichia coli lacZ in mouse chimeric embryos. Proc Natl Acad Sci USA 87:4712-4716.

Li JY, Boado RJ, Pardridge WM (2001) Differential kinetics of transport of $2^{\prime}, 3^{\prime}$-dideoxyinosine and adenosine via concentrative $\mathrm{Na}^{+}$nucleoside transporter CNT2 cloned from rat blood-brain barrier. J Pharmacol Exp Ther 299:735-740.

Lohse MJ, Klotz KN, Lindenborn-Fotinos J, Reddington M, Schwabe U, Olsson RA (1987) 8-Cyclopentyl-1,3-dipropylxanthine (DPCPX)—a selective high affinity antagonist radioligand for $\mathrm{Al}$ adenosine receptors. Naunyn Schmiedebergs Arch Pharmacol 336:204-210.

Luscher C, Jan LY, Stoffel M, Malenka RC, Nicoll RA (1997) G proteincoupled inwardly rectifying $\mathrm{K}^{+}$channels (GIRKs) mediate postsynaptic but not presynaptic transmitter actions in hippocampal neurons. Neuron 19:687-695.

Michel AD, Chessell IP, Humphrey PP (1999) Ionic effects on human recombinant P2X7 receptor function. Naunyn Schmiedebergs Arch Pharmacol 359:102-109.

Mihaylova-Todorova ST, Todorov LD, Westfall DP (2002) Enzyme kinetics and pharmacological characterization of nucleotidases released from the guinea pig isolated vas deferens during nerve stimulation: evidence for a soluble ecto-nucleoside triphosphate diphosphohydrolase-like ATPase and a soluble ecto-5'-nucleotidase-like AMPase. J Pharmacol Exp Ther 302:992-1001.

Miras-Portugal MT, Diaz-Hernandez M, Giraldez L, Hervas C, GomezVillafuertes R, Sen RP, Gualix J, Pintor J (2003) P2X7 receptors in rat brain: presence in synaptic terminals and granule cells. Neurochem Res 28:1597-1605.

Naemsch LN, Dixon SJ, Sims SM (2001) Activity-dependent development of P2X7 current and $\mathrm{Ca}^{2+}$ entry in rabbit osteoclasts. J Biol Chem 276:39107-39114.

Nieber K, Poelchen W, Illes P (1997) Role of ATP in fast excitatory synaptic potentials in locus coeruleus neurones of the rat. Br J Pharmacol 122:423-430

Nobile M, Monaldi I, Alloisio S, Cugnoli C, Ferroni S (2003) ATP-induced, sustained calcium signaling in cultured rat cortical astrocytes: evidence for a non-capacitative, P2X7-like-mediated calcium entry. FEBS Lett 538:71-76.

Norenberg W, Illes P (2000) Neuronal P2X receptors: localisation and functional properties. Naunyn Schmiedebergs Arch Pharmacol 362:324-339.

North RA (2002) Molecular physiology of P2X receptors. Physiol Rev 82:1013-1067.

Okada Y, Ozawa S (1980) Inhibitory action of adenosine on synaptic transmission in the hippocampus of the guinea pig in vitro. Eur J Pharmacol 68:483-492.

Pankratov Y, Castro E, Miras-Portugal MT, Krishtal O (1998) A purinergic component of the excitatory postsynaptic current mediated by P2X receptors in the CAl neurons of the rat hippocampus. Eur J Neurosci 10:3898-3902.

Pastor-Anglada M, Felipe A, Casado FJ (1998) Transport and mode of action of nucleoside derivatives used in chemical and antiviral therapies. Trends Pharmacol Sci 19:424-430.

Puthussery T, Fletcher EL (2004) Synaptic localization of P2X7 receptors in the rat retina. J Comp Neurol 472:13-23.

Ralevic V, Burnstock G (1998) Receptors for purines and pyrimidines. Pharmacol Rev 50:413-492.

Regehr WG, Delaney KR, Tank DW (1994) The role of presynaptic calcium in short-term enhancement at the hippocampal mossy fiber synapse. J Neurosci 14:523-537.

Salin PA, Scanziani M, Malenka RC, Nicoll RA (1996) Distinct short-term plasticity at two excitatory synapses in the hippocampus. Proc Natl Acad Sci USA 93:13304-13309.

Satoh T, Hosokawa M (1998) The mammalian carboxylesterases: from molecules to functions. Annu Rev Pharmacol Toxicol 38:257-288.

Scanziani M, Capogna M, Gahwiler BH, Thompson SM (1992) Presynaptic inhibition of miniature excitatory synaptic currents by baclofen and adenosine in the hippocampus. Neuron 9:919-927.
Schilling WP, Sinkins WG, Estacion M (1999) Maitotoxin activates a nonselective cation channel and a P2Z/P2X(7)-like cytolytic pore in human skin fibroblasts. Am J Physiol 277:C755-C765.

Sikora A, Liu J, Brosnan C, Buell G, Chessel I, Bloom BR (1999) Cutting edge: purinergic signaling regulates radical-mediated bacterial killing mechanisms in macrophages through a P2X7-independent mechanism. J Immunol 163:558-561.

Solle M, Labasi J, Perregaux DG, Stam E, Petrushova N, Koller BH, Griffiths RJ, Gabel CA (2001) Altered cytokine production in mice lacking P2X(7) receptors. J Biol Chem 276:125-132.

Sperlagh B, Kofalvi A, Deuchars J, Atkinson L, Milligan CJ, Buckley NJ, Vizi ES (2002) Involvement of P2X7 receptors in the regulation of neurotransmitter release in the rat hippocampus. J Neurochem 81:1196-1211.

Sperlagh B, Szabo G, Erdelyi F, Baranyi M, Vizi ES (2003) Homo- and heteroexchange of adenine nucleotides and nucleosides in rat hippocampal slices by the nucleoside transport system. Br J Pharmacol 139:623-633.

Stefanovic V, Mandel P, Rosenberg A (1975) Concanavalin A inhibition of ecto-5'-nucleotidase of intact cultured C6 glioma cells. J Biol Chem 250:7081-7083.

Steinberg TH, Newman AS, Swanson JA, Silverstein SC (1987) ATP4- permeabilizes the plasma membrane of mouse macrophages to fluorescent dyes. J Biol Chem 262:8884-8888.

Surprenant A (1996) Functional properties of native and cloned P2X receptors. Ciba Found Symp 198:208-219.

Takigawa T, Alzheimer C (2002) Phasic and tonic attenuation of EPSPs by inward rectifier $\mathrm{K}^{+}$channels in rat hippocampal pyramidal cells. J Physiol (Lond) 539:67-75.

van Galen PJ, van Bergen AH, Gallo-Rodriguez C, Melman N, Olah ME, IJzerman AP, Stiles GL, Jacobson KA (1994) A binding site model and structure-activity relationships for the rat A3 adenosine receptor. Mol Pharmacol 45:1101-1111.

Westfall DP, Todorov LD, Mihaylova-Todorova ST (2002) ATP as a cotransmitter in sympathetic nerves and its inactivation by releasable enzymes. J Pharmacol Exp Ther 303:439-444.

Westfall TD, Kennedy C, Sneddon P (1996) Enhancement of sympathetic purinergic neurotransmission in the guinea-pig isolated vas deferens by the novel ecto-ATPase inhibitor ARL 67156. Br J Pharmacol 117:867-872.

Westfall TD, Menzies JR, Liberman R, Waterston S, Ramphir N, Westfall DP, Sneddon P, Kennedy C (2000) Release of a soluble ATPase from the rabbit isolated vas deferens during nerve stimulation. Br J Pharmacol 131:909-914.

Wieraszko A, Goldsmith G, Seyfried TN (1989) Stimulation-dependent release of adenosine triphosphate from hippocampal slices. Brain Res 485:244-250.

Wu LG, Saggau P (1997) Presynaptic inhibition of elicited neurotransmitter release. Trends Neurosci 20:204-212.

Yao SY, Ng AM, Muzyka WR, Griffiths M, Cass CE, Baldwin SA, Young JD (1997) Molecular cloning and functional characterization of nitrobenzylthioinosine (NBMPR)-sensitive (es) and NBMPR-insensitive (ei) equilibrative nucleoside transporter proteins (rENT1 and rENT2) from rat tissues. J Biol Chem 272:28423-28430.

Young PR, McLaughlin MM, Kumar S, Kassis S, Doyle ML, McNulty D, Gallagher TF, Fisher S, McDonnell PC, Carr SA, Huddleston MJ, Seibel G, Porter TG, Livi GP, Adams JL, Lee JC (1997) Pyridinyl imidazole inhibitors of p38 mitogen-activated protein kinase bind in the ATP site. J Biol Chem 272:12116-12121.

Zimmermann H (2000) Extracellular metabolism of ATP and other nucleotides. Naunyn Schmiedebergs Arch Pharmacol 362:299-309.

Zimmermann H, Braun N (1999) Ecto-nucleotidases-molecular structures, catalytic properties, and functional roles in the nervous system. Prog Brain Res 120:371-385.

Zygowicz ER, Sunderman Jr FW, Horak E, Dooley JF (1977) Inhibition by concanavalin A as the basis for a specific assay of serum $5^{\prime}$-nucleotidase activity. Clin Chem 23:2311-2323. 